\title{
Praxe académica e culturas universitárias em Coimbra. Lógicas das tradições e dinâmicas identitárias
}

Student Rituals and University Cultures in Coimbra. The Logic of Traditions and Identity Dynamics

Coutumes académiques et cultures universitaires à Coimbra. Logiques des traditions et dynamiques identitaires

\section{Aníbal Frias}

Tradutor: Maria do Rosário Cunha

\section{(2) OpenEdition}

\section{Journals}

Edição electrónica

URL: http://journals.openedition.org/rccs/1147

DOI: $10.4000 /$ rccs. 1147

ISSN: 2182-7435

Editora

Centro de Estudos Sociais da Universidade de Coimbra

\section{Edição impressa}

Data de publição: 1 Outubro 2003

Paginação: 81-116

ISSN: 0254-1106

\section{Refêrencia eletrónica}

Aníbal Frias, «Praxe académica e culturas universitárias em Coimbra. Lógicas das tradições e dinâmicas identitárias », Revista Crítica de Ciências Sociais [Online], 66 | 2003, colocado online no dia 01 dezembro 2012, criado a 30 abril 2019. URL : http://journals.openedition.org/rccs/1147 ; DOI : $10.4000 /$ rccs. 1147

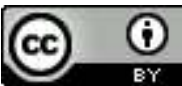




\title{
Praxe académica e culturas universitárias em Coimbra. Lógicas das tradições e dinâmicas identitárias '
}

\begin{abstract}
As culturas estudantis e universitárias em Portugal, muito pouco estudadas, são objecto de descrição e análise a partir do caso exemplar de Coimbra. Torna-se para tal necessário defini-las e entendê-las dentro de um quadro metodológico, social e histórico. Compreender a Praxe académica pressupõe articular a Academia e a Universidade, apreendidas na sua evolução mútua ou paralela como dois universos indissociáveis, ainda que autónomos. É necessário igualmente ter em conta os usos internos à Academia e as posições políticas, reflectidas parcialmente nas críticas à Praxe como as provenientes das Repúblicas, bem como os interesses económicos, com a repercussão do turismo sobre as "tradições" a conduzir à institucionalização e patrimonialização destas. Todas estas dimensões permitem fazer luz sobre as lógicas e as dinâmicas sociais de um fenómeno complexo em forte expansão, apesar dos excessos e das contestações recentes ecoadas e amplificadas pelos media.
\end{abstract}

\section{Introdução}

Mesmo num mundo secularizado e desencantado, não há decerto instituições que não ultrapassem o quadro de uma racionalidade funcional. A Universidade de Coimbra é, a este respeito, um exemplo particularmente esclarecedor. Neste sentido, a Praxe Académica garante a esta entidade social a sua dimensão simbólica. Associada aos estudantes, a Praxe Académica não é, de resto, senão a parte mais visível dos actos cerimoniais da comunidade universitária. Esta configuração complexa de práticas rituais, formais e festivas, acompanhada por uma constelação de imagens, de objectos e de mitos, confere ostensivamente à Universidade os sinais de uma singularidade reivindicada e de uma exemplaridade muito pouco estudada.

A Universidade de Coimbra, ou mais precisamente o Studium Generale (Estudo Geral), foi "fundada” no dia 1 de Março de 1290, em Lisboa, pelo rei D. Dinis. ${ }^{2}$ Até 1911, na Primeira República, permanece a única Univer-

\footnotetext{
${ }^{1}$ Manifesto o meu reconhecimento aos estudantes da Universidade de Coimbra, que generosamente me confiaram as suas palavras e experências. Uma primeira versão deste artigo beneficiou dos comentários do Prof. Joaquim Pais de Brito. Quero agradecer aos Profs. João Arriscado Nunes, que coordenou a minha investigação no CES, e Elísio Estanque, pelo convite que me dirigiu para participar no presente número.

2 A data é objecto de discussão entre os historiadores. Sobre o mito das "origens" da Universidade, ver Ruegg (1996: 4 e ss).
} 
sidade, com excepção para a de Évora, cuja existência decorre entre 1557 e 1759. Será por diversas vezes transferida para Lisboa; de 1308 a 1338 e de 1354 a 1377 tem a sua sede em Coimbra, onde vem a ser defitivamente instalada em 1537 por vontade de D. João III, que a sujeita a uma profunda reforma sob a influência do Humanismo. É constituída por quatro faculdades: Teologia, Cânones, Leis e Medicina, segundo a ordem hierárquica estabelecida. As alterações de envergadura em matéria de pedagogia e de arquitectura, introduzidas pelo Marquês de Pombal nos Statuts de 1772, inspiram-se nas ideias racionalistas das Luzes. ${ }^{3}$

A Praxe Académica, que em Portugal designa as tradições estudantis, refere-se, em primeiro lugar, às diversas humilhações, mais ou menos ritualizadas, que os estudantes mais antigos, os "doutores", impõem aos mais novos, os caloiros. A limitação de uma tal noção à esfera da coacção e à relação "doutor"/caloiro é assinalada pelos três símbolos da Praxe: a moca, a tesoura e a colher de pau. A Praxe Académica refere-se igualmente, ou referia-se, a brincadeiras por vezes violentas, a comportamentos lúdicos e paródicos: troças, partidas, piadas, de que dão testemunho as Memórias dos antigos estudantes. Esta restrição da Praxe deve incluir os registos subjectivo e representacional: o do vivido e o das percepções - variáveis, segundo os grupos e as épocas. Contudo, é a própria natureza destas tradições, como veremos, que evolui à imagem da Universidade e da sociedade. Tal como a Praxe, a tradição, a cultura e os rituais - que a definem ou com os quais é identificada - não são processos óbvios.

A Praxe Académica actual constitui, no seu conjunto, um "objecto social total”, segundo o sentido de Marcel Mauss (1983: 274). Com efeito, este fenómeno complexo e multiforme participa do ritual, do lúdico, do festivo, do jurídico, do económico, do artístico, do político; associa práticas, objectos, uma gíria, insígnias, gestos, palavras, literaturas, formas gráficas, elementos sonoros; implica inúmeros indivíduos, grupos entidades e organismos. A Latada e a Queima das Fitas, que dela fazem parte, são acontecimentos sazonais que regulam o calendário universitário, se não mesmo o da cidade. É necessário incluir também as repúblicas no campo da cultura académica, uma vez que estas possuem as suas próprias regras; se, nos dias de hoje e de um modo geral, as repúblicas são sobretudo críticas em relação à Praxe, até aos anos de 1960 foram o local do exercício de actos praxísticos. As tradições letradas ultrapassam largamente os seus aspectos lúdicos e os próprios estudantes. Pese embora as aparências, estas tradições marcam

\footnotetext{
${ }^{3}$ Sobre Pombal, ver a última síntese acerca do assunto dirigida por Araújo (2000); sobre a Universidade de Coimbra no século XVIII pré-pombalino, ver Fonseca (1995); sobre a história da Universidade em Portugal, consultar a síntese em curso (AA. VV., 1997).
} 
profundamente o espaço-tempo dos estudos, as sociabilidades e a própria instituição, desenhando os contornos - variáveis - de um território académico, da vida universitária e local, das representações, das maneiras de ser e, por fim, do homo academicus (Bourdieu, 1984). A Praxe, tal como as cerimónias professorais, participa, em contrapartida, da definição social, se não institucional, da Universidade de Coimbra, dos seus actores, de alguns dos seus costumes, do seu território ou dos seus mitos (Cruzeiro, 1990).

O presente artigo tem uma dupla finalidade: determinar as principais dimensões sociais da Praxe Académica e de algumas das cerimónias universitárias a partir da observação empírica das suas manifestações contemporâneas, e delinear a sua dinâmica social e histórica.

\section{I - Pressupostos teóricos: lógicas e dinâmicas das tradições}

Entre os registos que permitem compreender a lógica social da Praxe e a sua dinâmica histórica, consideraremos dois registos principais, cada um deles com dois eixos: por um lado, a homologia Universidade/Academia e a articulação entre as regras e as práticas, e, por outro lado, as estratégias identitárias entre estabelecimentos de ensino superior em Portugal, assim como a questão da Praxe e dos seus críticos.

\section{Lógicas da Praxe}

\section{Universidade/Academia}

Em Portugal, a palavra "Academia" refere-se aos estudantes (universitários, em primeiro lugar) eventualmente agrupados em torno de uma Associação Académica e constituindo, a diferentes níveis segundo as épocas e os locais, uma sociedade dotada de autonomia e centrada em sociabilidades e culturas mais ou menos homogéneas e partilhadas. ${ }^{4}$ Paralelamente às cerimónias professorais, a Praxe Académica constitui o registo cultural dos estudantes. Muitos dos seus elementos materiais e simbólicos derivam das práticas institucionais. Embora autónoma, a sociedade estudantil retira da Universidade uma parte da sua lógica social. Esta lógica é a de uma ordem hierárquica e distintiva. É possível perceber e distinguir duas fontes principais das tradições estudantis, para lá das que são fabricadas e transmitidas no seio da Academia: uma provém da instituição universitária (capa e batina, título de doutor, apadrinhamento, anel, cores, hierarquia, oratória, etc.) e a outra está ligada aos meios popular e rural (roubos e enterros rituais, algazarra, fado, músicos, procissões, álcool, comportamentos de honra e ven-

${ }^{4}$ Sobre a noção de Academia, ver Prata (2002: 23-25). 
detta, "tipos" populares: tricanas e futricas, etc.). Estas influências são objecto de uma apropriação dinâmica, e mesmo "criativa", pela juventude estudantil, através de desvios de sentido e de empréstimos, e também pela via do humor, da caricatura, do grotesco, da farsa, da crítica ou ainda da sublimação poética, musical ou teatral. Por outras palavras, através da sua cultura herdada e, em parte, híbrida, a Academia absorve, de uma certa forma, os "contributos" externos, sejam eles universitários ou populares. Esta especificidade faz da Praxe a filha da Universidade, relação da qual retira a sua coerência estrutural e uma grande parte dos seus elementos materiais e dos seus comportamentos rituais e festivos.

\section{Regras e práticas}

Prestar atenção às Praxes de curso, percebidas nos seus pormenores e na sua realização concreta, favorece a comprensão do seu significado social. Essas acções podem ser confrontadas com as regras contidas nos dois últimos Códigos da Praxe (1993 e 2001). Este confronto permite avaliar a força das prescrições escritas e os desvios das práticas relativamente às regras. Os desvios - como, de resto, os ajustamentos - não se verificam rigorosamente "entre" a regra escrita e a prática dos indivíduos, mas entre o quadro situacional das práticas, implicando conhecimento, valores e interesses, e a representação que um indivíduo ou um grupo tem dessas regras. Estes desvios vão desde a aplicação à letra, pelo menos intencionalmente (com a referência explícita ao Código - ou antes, ao conhecimento que dele se tem), até à transgressão ou mesmo à invenção de comportamentos, passando pela desactivação ou abandono dos ritos "tradicionais". É o caso das humilhações (canelões, palmatoadas) que decorriam, até 1900, sob a Porta Férrea, a via de acesso - figurando um arco de triunfo - ao espaço histórico da Universidade. Estes actos foram abandonados na sequência de críticas intra e extra-académicas (i.e. mediáticas), traduzindo uma alteração das sensibilidades colectivas. $\mathrm{O}$ abandono de um comportamento que caiu em desuso não pertence ao mesmo registo, não parece obedecer às mesmas razões a que obedece uma rejeição individual ou colectiva "motivada" de determinados elementos ou do conjunto das tradições - se, por acaso, isso alguma vez foi possível. A este respeito, seria necessário estabelecer tipos e graus de desvios, apontando os respectivos efeitos. Consideremos apenas um exemplo. O hábito de "julgar" os caloiros no espaço das repúblicas, à imagem do julgamento do tribunal universitário no tempo do foro académico ${ }^{5}$, aca-

\footnotetext{
${ }^{5} \mathrm{O}$ foro académico era uma jurisdição universitária, com um tribunal, uma prisão e uma polícia próprios, em vigor até 1834 .
} 
bou com o movimento "anti-Praxe" da crise académica de 1969. Contudo, na década de 1990, algumas tertúlias ${ }^{6}$, contornando simultaneamente a contestação da Praxe pelas repúblicas e a autoridade do Conselho de Veteranos (o órgão guardião da Praxe), reactivaram aquela "tradição", mas deslocando-a para casas particulares. Do mesmo modo, o último Código, datado de 2001, reconfigurou as regras do Julgamento do Caloiro, alargando o direito de exercer este ritual às casas comunitárias ${ }^{7}$, como os Cow Boys, que, não sendo reconhecidas pelo Conselho das Repúblicas, o podem ser, no entanto, pelo Conselho de Veteranos.

A observação das mudanças é induzida por duas hipóteses. A primeira prende-se com o facto de que, segundo a etnometodologia, uma regra só tem sentido reapropriada, isto é, compreendida, nomeada e praticada. É o que Alain Coulon designa por "praticalidade da regra" (1997: 156). A segunda diz respeito à própria natureza das tradições que, longe de se transmitirem mecanicamente, sem alterações, são, pelo contrário, dinamizadas pela sociedade onde se encontram ancoradas. Em vez de se conservarem idênticas, são ajustadas e reinvestidas, no plano social e simbólico, pelos (ou por alguns) membros da comunidade onde estão (re)activadas e vivas - não sem uma parte de esquecimento. Mas são, de facto, os registos das práticas e das regras que obedecem a razões sociais e a modalidades cognitivas distintas.

\section{Dinâmicas da Praxe}

\section{Processo sócio-histórico}

O aparecimento nos textos, por volta de 1860, da palavra "Praxe" traduz mais do que uma simples deslocação de sentido. Desde essa data, a Praxe Académica reúne numa mesma unidade semântica os comportamentos característicos, e até aí dispersos, do universo académico. Esta expressão sintética e sui generis emerge, devido a um aumento da concorrência entre a velha Universidade de Coimbra e outros estabelecimentos de ensino superior, técnico-científicos, então criados em Lisboa e no Porto (Cruzeiro, 1979).

\footnotetext{
${ }^{6}$ A tertúlia é uma espécie de círculo ou de clube informal, onde os estudantes se reúnem por afinidades afectivas ou por Faculdades, a fim de conviverem, conversarem, beberem, tocarem instrumentos musicais ou praticarem actos de Praxe, como a formação de uma "trupe". Embora as tunas académicas, pela sua natureza convivial e cultural, se aproximem das tertúlias, possuem contudo um carácter mais institucional, pelo facto de serem sediadas na Associação Académica de Coimbra (AAC) e pela realização de espectáculos de músicas e cantos tradicionais.

${ }^{7}$ Estas casas, apesar de funcionarem de forma comunitária, não são repúblicas. Por isso, não gozam, nem do prestígio, nem das vantagens socioeconómicas, nem de todas as prerrogativas praxísticas das repúblicas.
} 
Uma competição que se acentua depois da instauração da República, com a criação das Universidades de Lisboa e do Porto em 1911, e, sobretudo, depois do 25 de Abril de 1974, com a multiplicação das Universidades Novas e dos Institutos Politécnicos ${ }^{8}$, em busca de uma legitimidade e de uma "alma".

A crise académica de $1969^{\circ}$, apesar de se desencadear em Coimbra, tem repercussões nacionais. Durante as manifestações colectivas, elementos tradicionais - como o fado, transformado em balada ou canto de intervenção com Zeca e Adriano, o "luto académico" (greve às aulas), traduzido no uso da capa e batina completamente fechadas, ou ainda o hino académico, colectivamente entoado no fim de um cortejo silencioso, em 1968, em comemoração da Tomada da Bastilha ${ }^{10}$, - constituíram vectores federativos da Academia e, simultaneamente, as marcas de uma "cultura de oposição", conforme a expressão de Luís Reis Torgal (1999: 252). A partir de 1969, e sobretudo depois do 25 de Abril de 1974, os costumes académicos são globalmente rejeitados, juntamente com o poder fascista que os havia assimilado. As repúblicas, ou seja, as casas comunitárias de estudantes, que desempenharam um papel central nos conflitos da década de 1960, procedem a uma tabula rasa relativamente a uma parte dos seus arquivos, frescos murais e outros objectos deixados pelas gerações anteriores (cf. infra). Entre 1978 e 1980, alguns elementos da Praxe Académica foram reactivados. Esta "restauração", que despertou a polémica e até mesmo o conflito, desenvolveu-se em várias etapas: em 1978, com a ressurreição do fado, o qual havia sido parcialmente destronado, desde o início dos anos de 1960, pelo canto de intervenção (Frias, 2003b); com o apoio da direcção social-democrata da AAC, surge, em 1979, uma Semana Académica, "uma Queima das Fitas disfarçada" (Lamy, 1990: 834); e, sobretudo, em 1980, com a realização de uma Queima das Fitas pública, o regresso da capa e batina e das Praxes. A implantação, nos anos de 1980/1990, nas novas Universidades e nas escolas de ensino superior, de Praxes híbridas, onde os empréstimos do modelo coimbrão se associam a traços locais, conduz a projectos identitários e a estratégias distintivas ${ }^{11}$.

\footnotetext{
${ }^{8}$ Desde 1974, o número das Universidades Novas, públicas e privadas, é mais de uma dúzia; os Institutos contam-se às centenas, na sequência do acentuado aumento do número de estudantes (de ambos os sexos) e de Licenciaturas (Barros apud Estanque e Nunes, 2002: nota 1).

${ }^{9}$ Cf. Cruzeiro (1989).

${ }_{10}$ Trata-se de um episódio sucedido em 25 de Novembro de 1920, quando alguns estudantes sitiaram o espaço reservado aos professores, situado junto da AAC. Este acontecimento foi significativamente reactivado no período contestatário, tal como, por exemplo, O Badalo, o jornal das repúblicas ressurgido em 1965.

${ }^{11}$ Para um exemplo de estratégia identitária no caso da Universidade de Braga, ver a nossa DEA (Mestrado), Frias (1992).
} 
A análise sócio-histórica mostra que as tradições estudantis e, de uma forma mais abrangente, a Universidade, foram alvo de alterações nos seus conteúdos, nas suas práticas e nas suas representações (Frias, 1998a). O que é particularmente verdadeiro em relação ao período que se situa entre o final do século XIX e os nossos dias. Estas alterações ocorrem em duas vertentes imbricadas. A primeira é interna às transformações da instituição (e do campo) universitária e à própria dinâmica, por vezes conflituosa, de qualquer tradição - ou instituição. A segunda reflecte as transformações sociais e políticas da sociedade portuguesa, do ponto de vista das normas e dos valores académicos.

\section{Praxe/Anti-Praxe}

O sentido e a finalidade da Praxe devem ser, como sucede com qualquer objecto social, relativizados nos planos histórico e sociológico, assinalando-se a variação das significações sociais, segundo as épocas e os grupos, segundo os costumes e os interesses em questão. Não sendo assim, corre-se o risco de cair num discurso incontrolado e essencialista, nem sociológico nem histórico.

O Mestrado em Sociologia de António Revez sobre a Praxe de Évora, acumula estas ambiguidades metodológicas, dada a precária aplicação do princípio weberiano que distingue entre a relação com os valores (incluídos no objecto) e os juízos de valor na relação (pessoal) com o objecto. Assim, como conclusão do seu inquérito, o autor (Revez, 1999: 306) enuncia o seguinte: "a Praxe eborense é, como as outras, reaccionária, conservadora, retrógrada, anti-democrática, hierárquica, paternalista, disciplinadora, tradicionalista, integracionista, cristã, culpabilizadora e castigadora, antiquada, sexista, organicista, formalista, normativa, e maniqueísta”. Numa perspectiva mais ampla: tentar compreender o jogo dos comportamentos "praxistas" e "antipraxistas" pressupõe, antes de mais, reconhecer uma maior complexidade na oposição praxista/antipraxista ${ }^{12}$, demasiadamente redutora e dualista, procedendo a uma seriação das críticas e dos tipos de relação com a Praxe, no seio da Academia. Considerando a vivência estudantil, o uso da capa e batina não é suficiente, só por si, para marcar uma adesão ou um afastamento relativamente à Praxe; o mesmo se pode dizer, aliás, da simples participação na Queima das Fitas que, tendo-se tornado na "festa da Academia", solicita toda a gente. Assim, por exemplo, o uso da capa e batina por parte de um membro de uma secção cultural, musical ou

\footnotetext{
${ }^{12}$ Não sendo explicativa, esta oposição permanece, contudo, operante nas tomadas de posição no interior da Academia.
} 
desportiva da Associação Académica de Coimbra (AAC) obedece, antes de mais, aos hábitos internos das respectivas secções, tornando obrigatório o uso do fato tradicional por ocasião das representações. Fora do espaço académico a secção está, com efeito, "em representação" em todos os sentidos da expressão: devido ao espectáculo público que dá e porque funciona como uma delegação da AAC, tornando-se, no estrangeiro, numa espécie de "embaixada" da Universidade. O mesmo acontece quando se trata, como vimos, de contestações colectivas (cf. o luto académico em 1969, ou as manifestações da ACC em Lisboa, etc.). A capa assume um sentido diferente, conforme seja usada como uma marca tradicionalista ou simplesmente identitária no seio da Academia, ou como um sinal de identificação relativamente às outras Universidades. O que ocorre, pois, é uma separação, relativa, entre um uso comum, próprio de um grupo constituído, e uma reivindicação ideológica de valores "praxistas", distintivos e hierárquicos.

Por outro lado, a compreensão dos fenómenos "Praxe" e "anti-Praxe" e das suas gradações (indiferentes, praxistas, etc.) exige uma particular atenção ao modo como os indivíduos e os grupos (ou os media) chegam - ou não - a um consenso na criação das categorias e das classificações, e na delimitação das fronteiras social, semântica, territorial, temporal, ética. É por isso que, até a um certo ponto, as críticas da tradição e a tradição das críticas constituem um outro eixo dinâmico da Praxe Académica.

\section{Violência, Escola e críticas aos rituais estudantis}

A explicação das reacções sociais às tradições estudantis é absolutamente evidente. Essa explicação tem que ver, em parte, com as transformações estruturais ocorridas nos anos de 1960/1980 no seio da Universidade - os seus públicos, as suas funções, as suas imagens -, com o investimento e a implantação local da instituição escolar ou universitária, com os usos sociais das tradições, com as sensibilidades colectivas em matéria de violência, com a evolução do sistema dos valores fundadores dos comportamentos. As práticas rituais estudantis, as suas normas reguladoras e os seus excessos são inseparáveis da Escola - nomeadamente da Universidade - onde se desenvolvem, e da globalidade da sociedade. Estão ligadas aos códigos e aos costumes sócio-históricos em vigor entre uma população jovem, celibatária e durante muito tempo masculina, e às sensibilidades colectivas em meio urbano. Por outro lado, neste domínio como em qualquer outro, não poderia existir um grau de "violência zero", nem um critério normativo absoluto.

A violência estudantil, seja ela ritualizada ou transgressora, simbólica, psicológica ou física, não pode ser dissociada da que esteve em vigor durante 
muito tempo na instituição escolar e da qual talvez apenas subsistam, nos dias de hoje e em alguns países, sanções e punições atenuadas e sem relação com a superfície corporal a que se dirigiam os castigos de antigamente. Se as sevícias e a violência física legítima, a da instituição, se suavizaram recentemente, a Escola do século XIX é descrita por Jean-Claude Caron (1999) como um "meio violentógeno", incluindo entre os estudantes, à imagem de outros meios sociais. A própria história da Escola apresenta disso a marca ou o estigma: "A violência foi sempre o familiar modo de expressão da população das faculdades e das grandes escolas” (Coutin, 1969: 9).

Os estudantes e a Escola devem ser situados no todo social e nos seus níveis de sensibilidade, embora as formas e as expressões da violência escolar obedeçam a determinadas modalidades particulares. E isto, por três razões: apesar de autónoma, a Academia integra a Universidade, sujeitando-se às suas normas pedagógicas; muitos conflitos da Academia, como já se viu, são o resultado de reacções contra medidas disciplinares da Universidade (exclusões, reprovações); alguns hábitos e objectos da instituição são alvo de uma apropriação pelos estudantes, tal como a autoridade "pedagógica" dos mais velhos sobre os mais novos, os castigos "escolares" administrados com um dos símbolos da Praxe - a colher de pau ou, antigamente, a palmatória utilizada pelos professores. A palmatória, objecto simbólico e estatutário, incarnou durante muito tempo a autoridade e a função do mestre. É com a palmatória que ele aponta as letras do alfabeto no quadro, que apruma os corpos e os espíritos, que marca o ritmo dos exercícios. Integrado e ajustado ao mundo regulamentado e ordenado da aula, este instrumento foi identificado - positivamente - com o acto educativo, do mesmo modo que o livro ou o ditado; há que situá-lo, além disso, numa cultura material da sala de aula, ao lado da carteira, do giz, dos cadernos, dos mapas e das imagens.

A contestação da Praxe em Portugal não é coisa recente. Em textos que datam da primeira metade do século XVIII, já alguns estudantes atacam, por vezes em forma versificada, as assuadas rituais ou verbais: canelões e investidas. Por seu lado, António Verney e António Ribeiro Sanches sugerem, para o primeiro caso, um "rigoroso castigo", sem excluir a pena capital contra os que incomodam os novatos ${ }^{13}$, sugerindo, para o segundo, o fim das "bárbaras e indecentes investidas, feitas com violência e sem respeito, estando os agressores armados como para o assalto a um castelo" (Sanches, 1959: 144). Note-se, antes de mais, que é o conjunto do mundo académico que se vê atravessado por conflitos e turbulências, de que a disputatio, essa

13 Citado por Prata (2002: 255, nota 769). 
arma oratória, enquanto exercício oral formalizado, é, sem dúvida, apenas um género particular derivado e muito eufemístico do "assalto verbal": os letrados imitavam no seu espaço os torneios de armas dos bellatores.

Os textos falam de tumultos entre estudantes de diferentes colégios ou regiões de origem, referindo-se, por vezes, a tumultos entre nationes, de conflitos que, implicando dois indivíduos, eram frequentemente alargados, por solidariedade, aos grupos respectivos, de desordens entre professores, de rixas em que se defrontavam os escolares solidários com a autoridade reitoral ou docente, ou com a população urbana. As razões abrangem questões de honra e de hierarquia; têm que ver com o identitário, o território ou simplesmente com a vontade do momento. Sob o termo muito geral de "violência" - assim considerada no âmbito do aparelho judiciário (donde provém a maior parte dos documentos sobre estes excessos consignados ou sancionados) - podem distinguir-se as agressões físicas de defesa ou de ofensa, seja com a ajuda de uma arma (nos meios aristocrático e letrado), seja com um pau ou apenas com a mão (o que ocorre frequentemente com o povo). Estes comportamentos "anómicos" regulamentados e estas "maneiras" expressivas da agressão resultam de uma justiça ou de um sentimento de justiça privada, individual ou colectiva, que a honra ou o interesse determinam. A violência exprime-se também por provocações verbais que, pelas consequências sociais, são de natureza lúdico-ritual ou verdadeiros "delitos de palavra" que levam à prisão da Universidade; exprime-se ainda por gestos e olhares em forma de provocação, com as inevitáveis consequências.

Todo o século XVIII, e mesmo depois, apesar das proibições que se repetem a partir dos séculos XV e XVI, está marcado por acertos de contas sangrentos entre bandos escolares armados, que transportam para o espaço dos estudos os conflitos e a cizânia: o Rancho da Carqueja, em 1720-1721 (Fonseca, 1995: 410-417), o Rancho dos Doze, em 1737 ou ainda em 1803. Em 7 de Janeiro de 1727, o rei D. João V suspende as práticas rituais, devido às mortais investidas aos novatos. O elemento estrutural que explica um tal comportamento tem que ver com a quase impunidade, que se estendia aos respectivos criados e famílias, dos universitários face à justiça real, impunidade que, de facto, lhes era garantida pelo foro académico desde 1309 até 1910, se não mesmo até aos dias de hoje. As descrições de 1740-1745, contidas na compilação Anno Noticioso e Historico, "mostram homens cheios de violência" (Delgado, 1991: 238). Na época, as palavras-chave associadas aos "estudantes" em particular e a determinados "jovens" citadinos em geral são: "turbulentos", "desenvoltos", "abusadores", "furiosos". Note-se que os termos "desonesto" e "escandaloso", que figuram muitas vezes 
nos textos históricos, nomeadamente nos Estatutos da Universidade, não se referem a actos cruéis, mas a desordens sociais. O seu sentido é, de propósito, suficientemente fluido para abranger toda a espécie de ilegalidades. A transgressão de um estatuto ou de um "estado", a não conformidade em matéria de costumes estabelecidos, são do domínio do registo da violência simbólica: ser surpreendido, de noite, com uma "mulher de vida escandalosa" constitui uma dupla afronta às autoridades, pelo facto de desobedecer à regra do recolhimento depois do anúncio das vésperas e pela presença de mulheres "suspeitas" na Alta; andar sem o tradicional fato negro ou usar cores e tecidos proibidos ou impróprios da sua "condição", pelo menos desde os Estatutos de 1503; andar pelas ruas com um número demasiado ou insuficiente de criados contraria o decoro e até mesmo a etiqueta; o que insulta ("assalto verbal") alguém detentor de uma certa "consideração" incorre numa sanção, etc. Estas atitudes "extravagantes" expõem os respectivos infractores a uma pena gradual - da reprimenda à multa e à prisão. Os comportamentos estudantis oscilaram, de resto, durante muito tempo, entre a sociabilidade viril exacerbada entre grupos de iguais (desafios, bravatas, vaidade) e a anomia (dos roubos às injúrias e ao homicídio), entre as contestações ruidosas e a conflitualidade lúdica integradora.

Durante o século XIX, a tendência é para a atenuação das práticas violentas no meio universitário. Entre os factos e a percepção dos factos manifesta-se uma intolerância acrescida em relação aos excessos colectivos, particularmente em relação aos que atingem a "propriedade" alheia: corpo físico ou espaço privado. Mas, perante as críticas em particular, a prática corrente do imposto que obriga o caloiro a pagar um tributo, a fim de integrar a Lusa Atenas, parece atenuar-se, vindo a ser alvo de críticas e depois proibido em 1848 (Cruzeiro, 1990: 178, nota 1); no mesmo sentido, a opinião pública, em processo de se constituir, põe em causa as troças (piadas, insultos): "Elas dariam origem a conflitos graves e a funestas consequências", vindo a ser "condenadas na imprensa e em outros sectores da opinião" (Roque, 1991: 262). Contra uma certa impunidade praticada pelos tribunais relativamente aos estudantes e às suas Praxes (Coimbra, 1991: 329), o jornal O Conimbricense, de 3 de Agosto de 1886, afirma o seguinte, referindo-se às troças: "Sabemos até que ponto o fogo e a verdura da mocidade levam à exaltação, mas o que se viu não são divertimentos toleráveis, mas selvajaria" (apud Coimbra, 1991: 330). De violentas que eram, estas troças transformaram-se lenta e parcialmente em chalaças e em cenas lúdicas, no final so século XIX (Coelho, 1902; Costa, 1925). Esta passagem das agressões físicas aos assaltos verbais é assinalada por um contemporâneo (Carvalho, 1902: 5, 9-10) que refere que a "Praxe academica" [sic] é uma "sobrevivên- 
cia" e "uma codificação da velha selvajaria atenuada"; informa que as cacetadas e os canelões são uma coisa "felizmente, hoje quase extinta"; e acrescenta: durante "esta prática, os veteranos fazem uma prudente distinção entre os caloiros valentes e os que são raquíticos, atáxicos e tísicos”. Esta distinção é decerto o sinal de uma nova prudência e sensibilidade, mas pode ver-se aí também um indício de outra ordem: o de uma moral viril de mistura com a honra, que reaparece nas palavras pronunciadas pelo "doutor" de uma trupe (17/10/2001) perante as lágrimas de um caloiro "rapado": por ser caloiro não se é menos macho.

Durante todo o século XIX, prolongaram-se as críticas à Praxe e aos seus aspectos menos aceitáveis. Nesse sentido, José de Arruela, da Faculdade de Direito, publica entre 1902 e 1906 vários panfletos em tom anti-praxista; em 1905, cria um Grupo estudantil de recepção aos novos alunos que, em vez dos rudes canelões, das pastadas e dos rapanços, organiza actividades festivas e musicais, e propõe lançar flores aos caloiros. Recebe o apoio de professores republicanos. A partir da época liberal, as tradições académicas cristalizaram à sua volta posições políticas: republicanos contra monárqui$\cos /$ católicos. Esta bipolarização repetiu-se no seio da Academia, por volta de 1928-1929, entre "integralistas", apoiantes do golpe de Estado de Maio de 1926, e a área dos progressistas. Estes últimos, num manifesto anti-praxista, datado de 31 de Outubro de 1928, referem-se a uma Praxe "anacrónica, brutal, hipócrita, cobarde e iníqua" (Nobre, 1945: 78).

Em 1957-1959, os anti-praxistas (Vara, 1958) confrontaram-se com os partidários da Praxe - a começar pelo próprio redactor do então recente Código da Praxe (Andrade, 1959). Na época, o jornal Diário de Lisboa noticiou estes debates que, no entanto, ficaram confinados à Academia. É de assinalar um gesto simbólico: um decreto em latim macarrónico, emitido em 1959 pelo Conselho de Veteranos, faz de Flávio Vara, que ousara contestar os princípios da Praxe, um futrica: "Hoc indigena consideratus futrica debet esse" (apud Andrade, 1959: 57). Estas tensões redobraram durante o período fortemente contestatário que precedeu e se seguiu à crise académica de Fevereiro de 1969. Contudo, este esquema dual e, além disso, firmado numa base política, revela-se menos pertinente para explicar a dimensão das querelas infra-académicas, a partir dos finais dos anos de 1950. E isto porque, "depois de 1956, entra-se num novo espírito cultural de "defesa" da tradição e, simultaneamente, de "oposição" (Torgal, 1999: 250). Até 1969, data do principal conflito que opôs a Academia, quase unanimemente, ao regime governamental, a tradição é rejeitada, mas, por outro lado, alguns dos seus aspectos - como o fado, a capa e batina, o hino académico, a caricatura - ou dos seus órgãos - como os Conselhos dos Veteranos e das 
Repúblicas - participam no combate, com o objectivo de unificar e mobilizar. De tradicionalista, enquanto virada para um passado intencionalmente valorizado, conservado ou mitificado, a tradição torna-se num motivo de progresso, ficando associada à esperança da luta.

A Praxe - ou as imagens que cada um tem dela - voltou a irromper no cenário mediático (jornais, revistas, televisões) e político, chegando até ao gabinete do Ministro da Educação e até à Assembleia da República, em Janeiro de 2003. Logo nos primeiros dias de Janeiro, o Público ${ }^{14}$ publica uma informação sobre a queixa feita por uma aluna do primeiro ano da Escola Superior de Saúde de Macedo de Cavaleiros, pertencente ao Instituto Piaget. A referida aluna enviara uma carta ao Ministério, na qual denunciava as humilhações a que fora sujeita, no âmbito das Praxes próprias do início do ano escolar (simulações sexuais, roupa tirada). As autoridades da Escola aplicam-lhe sanções, e "testemunhos" publicados de colegas sustentam que ela exagerou os factos, acrescentando ainda que a sua frequência das aulas é irregular. É designada uma inspecção oficial, cujas conclusões são cautelosas: os factos dizem respeito a "danos de natureza civil, mas não são do domínio dos crimes de natureza pública" (in Diário de Coimbra, 30/01/2003). Algum tempo depois, a aluna apresenta queixa nos tribunais. O jornal nacional que divulgou os factos, ou antes a informação, é imediatamente secundado por toda a imprensa escrita e audiovisual. O Jornal de Notícias (27/03/2003) fala de "agressões [que] constituem um caso de polícia”. As críticas aos abusos voltam à ordem do dia, assim como a defesa das tradições. A iniciativa isolada desta aluna teve o poder de, um pouco por todo o lado e no seu próprio estabelecimento de ensino, encorajar outras atitudes de rejeição ou de recurso, ainda que, de um modo geral, essas atitudes permaneçam marginais.

Durante cerca de dez dias consecutivos, as opiniões, as tomadas de posição, as polémicas - do cidadão comum ao estudante, do (anti-)praxista ao político - foram divulgadas em várias dezenas de artigos de jornal, nas televisões, em revistas, até em sites da internet. Entre os "contra", os termos utilizados foram os seguintes: "irracionais", "bêbedos", "primitivos", "mastodontes"; falou-se de "instintos" e de comportamento "primário" e "irreflectido", servindo-se da Praxe e dos praxistas como insulto - dirigido a seres do passado e feitos de instintos. Uma doutora, leitora do Público (11/01/2003), refere-se a "estes rituais de imbecilidade", aos "fatos académicos tão tradicionais quanto ridículos", a essa "cerimónia reaccionária que é

\footnotetext{
${ }^{14}$ Ver também as edições dos dias seguintes, até ao fim do mês de Janeiro (e depois). Este "caso" surge num contexto de pedofilia no interior de um estabelecimento escolar católico, que provocou uma certa comoção, na proporção da sobremediatização de que foi alvo.
} 
a Queima das Fitas", a "atrasados mentais”. A polémica faz aparecer outras linhas de demarcação, como Lisboa contra o "provincianismo" de Coimbra (Pereira in Público, 9/01/2003), reactivamente defendido por uma leitora de Coimbra (Público, 11/01/2003), ou então os problemas ligados às Universidades, aos estudantes e à sociedade, os seus valores em extinção, para uns (João Almeida na Assembleia da República, deputado do PP), ou o seu inaceitável elitismo, para outros (Neves, in Público, 12/01/2003, doutorando no ISCTE). Este alarido tem consequências na forma (recodificação) e, a prazo, sem dúvida, no conteúdo dos costumes e dos rituais, uma vez que, em 30 de Abril de 2003, o Instituto Piaget assinou, a nível nacional, um protocolo sob a forma de uma carta de princípios orientadores nas Academias do Instituto. Este protocolo é uma "carta" de valor ético, pois destina-se a regulamentar os comportamentos no sentido de uma dupla conformidade: face ao regulamento interno da instituição escolar e face à lei republicana. O seu conteúdo é claro: "ao assinar este protocolo, a federação académica do Instituto Piaget compromete-se a pôr em prática as medidas eventualmente necessárias à adequação dos princípios institucionalizados nos códigos da Praxe académica adoptados por cada uma das associações de estudantes" (in Expresso, (21/04/2003). Em consequência, até à revisão dos códigos da Praxe, a Praxe está suspensa. Entretanto, a Escola "suspendeu" 25 estudantes que infringiram esta decisão administrativa, ao organizarem, na noite de 15 para 16 de Maio de 2003, um "tribunal de Praxe" de que resultaram agressões dos alunos mais velhos sobre os caloiros (Expresso, 21/05/2003.

Este e outros exemplos mostram que, nestes últimos anos, a referência à lei republicana se tornou insistente. As remissões para uma instância do Estado, com um grau cada vez maior de legitimidade e cada vez mais normativa, apontam para uma autoridade racional-legal e externa. Na qualidade de regulamentador, um tal modelo rejeita os comportamentos marcados pela violência privada e até ilegal, no âmbito das cerimónias de iniciação e da Praxe.

\section{II - Culturas universitárias}

Existe hoje em Coimbra um conjunto de cerimónias bastante diversas, que implicam a totalidade ou, mais frequentemente, uma parte do corpo docente: abertura solene do ano lectivo, defesa de tese, imposição das insígnias, doutoramento bonoris causa, funerais, comemorações, missas, protocolos, etc. Referir-nos-emos apenas a uma: o cortejo universitário.

O cortejo universitário é uma das manifestações mais "espectaculares" (para um olhar externo) do corpo docente, onde se misturam o cerimonial, 
a demonstração de poder, a afirmação - e o controlo - reiterada de uma identidade letrada e de uma ordem interna. A forma, a hierarquia e os elementos constituintes deste desfile ${ }^{15}$ quase não evoluíram desde o início do século XVI, com excepção do ponto de partida do seu percurso ou em matéria do fato estatutário. Excepção feita também, evidentemente, no que respeita aos contextos nacional, social e universitário profundamente transformados, o que não deixa de ter consequências no sentido destas cerimónias, como no das tradições em geral. Esta perenidade relativa, pelo menos na forma ou na intenção (dos discursos), é em si mesma significativa. Um tal desfile tem lugar e repete-se hoje, e com maior frequência ainda antes de 1910, nas grandes ocasiões: abertura solene do ano universitário marcando um novo ciclo temporal, doutoramento honoris causa e, antigamente, na cerimónia de defesa de tese ${ }^{16}$ ou no funeral de um membro da corporação. Os professores, situados no cortejo segundo a hierarquia das Faculdades e, dentro destas, por ordem de obtenção do grau de doutor (nos dois casos, portanto, segundo um critério de antiguidade - histórica ou temporal), usam ostensivamente o seu fato doutoral. Saem, em silêncio, da Biblioteca Joanina (da Capela, antes de 1910) e dirigem-se, a passo lento e com ar grave, ao ritmo de uma música solene executada pela orquestra da Universidade, para a grande Sala dos Capelos, esse “espaço sagrado" (Torgal, 1993b: 633). Um tal espaço, retirado do mundo profano e fechado sobre a élite dos professores, desenha uma verdadeira cosmologia que ordena os seres, os lugares, os gestos, as palavras, os sinais. Os membros do colégio dos doutrores ocupam o seu respectivo lugar em torno dos catedráticos, segundo a mesma ordem do desfile. Nesse local elevado, no coração da Universidade, onde, noutros tempos, a regra exigia que se falasse em latim (Via Latina), essa língua do saber e do segredo (Waquet, 1998), os professores repartem-se ainda segundo o duplo princípio da antiguidade. Mas, desta vez, esta ordem interna opera em função de uma orientação espacial: a do lugar ocupado pela cadeira-trono do Reitor. Este lugar/posição está no princípio de uma ordenação espacial, social e simbólica. O Reitor, a título da sua preeminência universitária, está autorizado a presidir às cerimónias e aos destinos do corpo académico que incorpora, até no uso neutro da cor negra congregadora do seu fato.

O complexo conjunto de práticas rituais, formais e festivas é reforçado por uma constelação de imagens (de reis, de reitores, de postais), de designações (Lusa Atenas, Alma Mater, colina sagrada, "cidade dos doutores”), de

\footnotetext{
15 Sobre um exemplo codificado de desfile académico, ver Clark (2002).

${ }^{16}$ A propósito do contexto histórico e político da defesa de tese, consultar Torgal (1993a); sobre a análise detalhada do seu cerimonial, ver Frias (2003).
} 
figuras tutelares (Minerva, rei D. Dinis, o "fundador", estátuas alegóricas, Rainha Santa Isabel), objectos-signo (selo, livro, ceptro, bandeira, cores, fato, aliança) e de mitos do domínio da História Sacra, das histórias lendárias e do religioso.

A Universidade está, pois, longe de se reduzir a uma instituição do saber, com uma finalidade pedagógica, com a função de atribuição de diplomas e colação de graus, bem como de produção e transmissão de um saber "escolar" orientado dos professores para os estudantes. "Pedagogia", "diplomas", "graus", "saber", "professores", "estudantes" - são noções, aliás, que têm de ser relativizadas num plano histórico e cultural, devendo o mesmo ser aplicado à própria noção de "Universidade". Considerada num sentido amplo, "a educação é um campo de comportamento simbólico" (Sapir, 1967: 53). Por isso, a Universidade pode ser encarada como um mundo cultural espacialmente ancorado e estruturado por um conjunto de interacções complexas, de saberes, de saber-fazer e de saber-ser, de valores e de usos, de crenças e de sinais de reconhecimento, de solidariedades, de hierarquias, de conflitos. Estes traços dependem de uma identidade, mais ou menos partilhada e consensual, que marca os contornos e a natureza da sociedade universitária, irredutível a um saber (mesmo letrado) e a "pessoas de saber" (Verger, 1997). Uma comunidade académica forma uma espécie de "aldeia intelectual", tão "fechada sobre si mesma" como "a maior parte dos aglomerados rurais" (Geertz, 1999: 195). Os seus habitantes, permanentes ou sazonais, não estabelecem apenas relações profissionais, mas também políticas, morais, pessoais, de linguagem (uma disciplina tem a sua "gíria" e o seu estilo).

No seio do cosmos universitário, cada área do saber constitui-se em torno do que Thomas Kuhn designou por "matriz disciplinar", inculcando hábitos ou, melhor, favorecendo a (des)abituação através de disposições científicas, assim como sociais, com a importância do manual onde os jovens investigadores aprendem o ofício. A aprendizagem processa-se, de resto, tanto de uma forma explícita, como segundo uma "pedagogia do silêncio". Este método veicula "modos totais de transmissão e práticas fundadas no contacto directo e duradouro entre o que ensina e o que aprende" (Bourdieu, 1992: 193). Relações construídas, quer directamente, nesses locais comuns do saber que são as salas de aula, colóquios ou laboratórios, ou então através de suportes multimedia e de reuniões inter ou transdisciplinares. Como não admitir, com efeito, pelo menos como hipótese, que um tal universo socialmente estruturado e prolongado no tempo - tendo em conta a totalidade do curso escolar-universitário - age como uma poderosa força formadora de hábitos? 


\section{III - Preparativos da Praxe de curso: o exemplo da Faculdade de Psicologia}

Apesar da sua força prescritiva e da sua legitimidade (junto dos praticantes da Praxe), o Código da Praxe não poderia abranger a gama completa dos actos de Praxe, nem mesmo confundir-se com eles, porque a prática da regra é de uma ordem diferente da regra da prática.

Antes de abordar o desenrolar efectivo e público das Praxes de curso, será interessante acompanhar de perto os "bastidores" de um tal fenómeno, através do exemplo seleccionado da Faculdade de Psicologia, cuja escolha ficou a dever-se ao acaso dos encontros no terreno, que conduziram a oportunidades de observação. E isto por várias razões. A primeira baseia-se na hipótese de uma socialização estudantil ocorrendo a montante da realização concreta dos rituais, entre os quais a Praxe de curso, a Latada e o Cortejo da Queima das Fitas. A segunda permite ver em acção, não apenas um saber-fazer, com as respectivas hesitações e execuções, mas também uma Praxe sendo colectivamente fabricada, no entusiasmo dos preparativos e, por vezes, das interpretações divergentes e até dos conflitos. Uma outra razão prende-se com a observação da parte que cabe, por um lado, à "espontaneidade" e à informalidade, e, por outro lado, da que corresponde aos procedimentos e medidas de natureza organizativa, o que decorre, cada vez mais, de uma racionalização dos comportamentos "tradicionais". Posteriormente - a jusante -, será possível observar os efeitos no conteúdo, assim como na forma, dos rituais e das sociabilidades estudantis a que leva uma tal organização. Finalmente, tratar-se-á de aferir, no fim do processo da Praxe de curso, incluindo preparativos e realização efectiva, a adequação ou o desvio entre o que é proposto, o que é abandonado ou afastado e o que se faz realmente, ao mesmo tempo que se questionará o sentido destes ajustamentos, abandonos ou distorções.

A Praxe de Psicologia fica a cargo, no quadro do núcleo de Faculdade (Nepce), de uma "Comissão Responsável pela Organização da nossa Praxe". Da observação minuciosa das operações discursivas, técnicas, práticas ou cognitivas desencadeadas por esta comissão organizadora da Praxe de curso, salientam-se vários pontos importantes, em matéria de Praxe. O primeiro diz respeito à existência e à própria designação de "comissão organizadora". O enunciado, tal como o objecto, apontam para uma lógica de gestão, conducente a uma racionalização dos actos de Praxe e, por fim, pela sobrecodificação a que estes ficam sujeitos, à sua institucionalização. Este processo reflecte-se, justamente, nas palavras "comissão" - que remete para uma lógica técnico-burocrática - e "organização" - que sugere a ideia de uma ordem e de um sistema de normas reguladoras de costumes e de comportamentos. 
Por isso, a coordenação da semana de Praxe passa i) por uma cronometragem do tempo, que deixa pouco espaço para desvios, para o ócio e para o acaso, e segundo a qual se marcam as horas de encontro - começamos às 10 horas $^{17}$-, se calcula a duração das actividades - iamos um dia inteiro, almoçávamos... - ou das sequências rituais - com 4 ou 5 provas aguentamos de manhã; depois do almoço, 5 minutos de aquecimento; ii) por pré-inscrições formais para as reuniões ou jantares - o jantar é para quem se inscrever; iii) pela preocupação com pormenores, pois está previsto dar a cada caloiro um "saco de sobrevivência" com uma garrafa de água, toalhas de papel, um saco de plástico para não poluir a cidade; iv) pela cartografia de que emergem visitas turísticas aos sítios mais emblemáticos, os mais simbólicos dos percursos - acabar no jardim da $A A C$ - ou lugares de Praxe - se não temos lugar que chegue vamos para o Jardim Botânico; v) por uma ordem de natureza sequencial - a partir dai o que fazemos? - ou de natureza organizativa é obrigatório haver 1 "doutor" para 2 caloiros; vi) pelas negociações e orçamentos - 3.500\$/grupo; o ano passado discutimos com "O Pratas" [um café da Alta] antes de passar por lá 2 ou 3 dias depois; vii) por um acerto das provas e dos dias - última pergunta antes de chegarmos à Alta; segunda-feira, dia da besta; viii) por uma espectacularização - fazer uma coisa tipo "mostra de caloiros" com cantar, strip tease, declaração à vida; pois temos que fazer alguma coisa original...

A aplicação destas prescrições obedeceu a outras lógicas, as da prática ou as do acaso meteorológico, o que conduziu, sem dúvida, à realização "espontânea" de uma Praxe flexível, pelo menos em parte, identificável com o investimento emocional dos actores: se a cronologia foi razoavelmente respeitada, o calendário previsto sofreu ligeiras alterações, abrandou-se o rigor do tempo calculado e até cronometrado, os jogos foram por vezes improvisados, a "aula fantasma" planeada teve de ser suprimida devido à ausência do professor cúmplice, ou a visita turística encurtada por causa da chuva. No entanto, apesar destes imponderáveis e destas falhas, as modalidades organizativas, presentes à escala de uma Faculdade (como da AAC e do Conselho de Veteranos), modificam, normativamente, o conteúdo material da Praxe em geral e da Praxe de curso em particular. Esta interferência manifesta-se ao nível i) de uma "inflexão" lúdica e eufemística em detrimento das humilhações mais ou menos pesadas, inflexão essa reforçada pela corrente crítica, tanto interna, como externa ao mundo académico: neste ano, arrastar os caloiros pelo corredor para os sujar é considerado demasiado degradante; é adoptada a expressão big caloiro em substituição

${ }^{17}$ Os itálicos remetem para as próprias palavras dos estudantes. 
de big besta, demasiado insultante; ii) da consideração pela vontade do caloiro ou pelo abrandamento das penalidades: queres beber, bebes; meter fitas cor de laranja à volta do pescoço é melhor que cordas; iii) dos percursos do género rallye e das visitas turísticas (não há provas, só passeio), onde as provas lúdico-rituais são acompanhadas pelo consumo socializante de um copo e pela "descoberta" do lugar.

Estes ajustamentos modificam também a natureza da Praxe. Em primeiro lugar, ao efectuarem uma separação (parcial) entre a submissão/humilhação e a socialização/integração, o ritual académico atenua-se, metamorfoseando-se até num momento lúdico e festivo: um grande dia, como diz a coordenadora. Note-se que a Praxe está significativamente a cargo da comissão "desporto e tempos livres". Em seguida, e correlativamente, ao redefinir a categoria de caloiro. Se este continua a ser insultado ou coagido, os "doutores" fazem acompanhar as suas invectivas e manifestações de poder de toda uma série de sinais, como o esboço de um sorriso ou o uso particular da capa e batina, remetendo para uma metalinguagem. Estes sinais têm, normalmente, como efeito a neutralização do "valor de verdade" primeira das injúrias e humilhações (carga negativa, violência), precisamente por essas provocações e esses excessos se encontrarem inseridos numa lógica de tipo lúdico e ritual. Quando não é o próprio quadro situacional imanente, constituído pelas interacções regulamentadas dos actores, a orientar a interpretação émica e a reacção adequada, induzida pelo "sentido do jogo" e a forma ritualizada das "respostas". Se o caloiro é relegado para o domínio da animalidade ("besta") ou identificado com uma criança de mama (presença das fraldas, do biberão, etc.), os mais velhos concedem-lhe de boa vontade alguns "direitos", como os de ter uma palavra e uma vontade que lhe permitam (formalmente) recusar as humilhações ou até declarar-se "contra a Praxe". ${ }^{18}$ Além disso, estes desvios materializam uma rearticulação, não só da relação "doutores"/caloiros, mas também da bipolarização, até ao momento composta por elementos exclusivos, tradição/modernidade. Neste último caso, se “a tradição" está genericamente presente enquanto norma - ideológica - positiva (vamos com a tradição) ou negativa (...são preconceitos) ${ }^{19}$, ela torna-se, tanto na prática como nas intenções, passível de ser modificada (podes modelar com a tradição), ou mesmo "adaptada", sem que o seu "espírito" seja necessariamente alterado (pelo menos, assim se pensa). A afirmação de

${ }^{18}$ Em outros locais, como em Évora, pode ver-se o indício de uma relativa "democratização" das regras da Praxe na passagem, ocorrida nos últimos anos, do estatuto de "Notável indefectível", isto é, veterano vitalício, para a eleição pelos outros "Notáveis".

19 Segue-se o diálogo completo: "- ... Saias [da capa e batina] por cima do joelho! - E porquê isso é mal? - Ó B* é tradição! - São preconceitos”. 
"tradições, devidamente ajustadas aos nossos dias de hoje" está presente, pela primeira vez, no Código da Praxe de 1993 (p. 14). Mesmo se essas tradições, como observámos, quase não evoluem ao nível dos Códigos, uma afirmação como a referida constitui um sinal, ou um efeito retroactivo, de um contexto de crescente indiferença e, simultaneamente, de contestação da Praxe, tanto externo como interno à Universidade. ${ }^{20}$

O que, finalmente, tem como consequências alterar a dinâmica da tradição, agindo por imitação/distinção a todos os níveis (entre Universidades, entre Faculdades, entre cursos (temos de fazer alguma coisa original), e interferir nos planos temporais: concretamente, as referências operantes, as que são reactivadas ou as que são rejeitadas pelos estudantes, remetem para "o ano passado" ou, no máximo, para dois ou três anos antes. Um limite cronológico que se confunde com a própria experiência que os estudantes têm da Praxe e da sua presença na Universidade. Com base num conhecimento mútuo favorecido pelo curso e por ocasião de uma reunião preparatória onde circulam palavras, recordações e projectos, elabora-se um conjunto de histórias praxísticas individuais. Um tal horizonte, feito de experiências vividas colectivamente, forja uma profundidade de memória que, em termos da operatividade presente, é toda de "superfície", por assim dizer. Sinal da modernidade, uma tal atenuação é talvez indício de uma "destradicionalização" dos valores - sociais - ligados ao passado, em benefício de um tempo presente (hedonista) ou das promessas de um futuro (profissional, existencial) que, como se diz, os estudantes têm à sua frente.

\section{IV - Praxes de curso}

A abertura solene da Universidade de Coimbra dá início, cerimonialmente, a um novo ciclo de estudos: em torno de S. Lucas, desde a Idade Média, no dia 18 de Outubro. Do mesmo modo, pode ver-se na concentração das Praxes de curso, nomeadamente na "Semana de recepção ao caloiro", no mês de Outubro, e, sobretudo, na Latada ${ }^{21}$, no princípio de Novembro, um "limiar" simbólico e temporal que anuncia um novo ciclo praxístico. Este limen pode variar, embora ligeiramente, segundo os lugares e a sua história. É o caso da Universidade de Évora, onde o 1. ${ }^{\circ}$ de Novembro, "Dia

\footnotetext{
${ }^{20}$ Cf. os conflitos entre as repúblicas e os praxistas, nos anos de 1980; esta oposição crítica está hoje reactivada com as Marias em Coimbra, com o M.A.T.A. (Movimento Anti-Tradição Académica) em Lisboa, ou com a Ovelha Negra, agora Garfo, em Braga. Esta mudança é visível na introdução do Manual do Caloiro onde, desde há uma dezena de anos, aparecem referências aos deveres e, também, aos "direitos" dos novos alunos, até à iniciativa estratégica, por parte de estudantes contra a Praxe da Faculdade de Letras de Coimbra, em 2001, de distribuir um Manual do Primeiranista. ${ }^{21}$ Não é possível, no âmbito deste artigo, desenvolver o conjunto das festas e rituais académicos: Latada, Queima das Fitas, rasganço, etc.... Ver Frias (2003a).
} 
da Universidade", isto é, da sua fundação em 1559, concentra, simultaneamente, cerimónias institucionais, rituais académicos ("Chocalhada", "A largada do sapato"), um "juramento" dos estudantes perante o reitor ${ }^{22}$ na Sala de Actos, um cortejo, o baptismo das "bestas" - promovidas nesse dia a "caloiros" - no Claustro Maior, e o direito de todos os estudantes usarem a capa e batina. ${ }^{23}$

Em Coimbra, a partir das inscrições dos novos alunos, antes mesmo do início das aulas e da abertura cerimonial da Universidade, as Praxes de curso invadem a Alta da cidade, onde se situa a Universidade. Como em outros locais, o mês de Outubro concentra a maior parte das Praxes. Trata-se, pois, de um fenómeno simultaneamente regular (cíclico) e periódico, embora estas Praxes possam, em princípio (mas, de facto, quase nunca), estender-se durante todo o ano universitário. Esta primeira série de rituais de tom lúdico, funcionando como rito de passagem (Frias, 1998b), obedece às três sequências lógico-temporais determinadas por Arnold Van Gennep (1981): ritos de margem (isolamento, morte social), ritos de pôr à prova (testes "escolares", aprendizagens, iniciações, resistência física e ao álcool) e ritos de integração (apadrinhamento, baptismo, comensalidades). Trata-se de comportamentos estereotipados que hão-de renovar-se e estender-se por todo o curso universitário, até ao ritual do rasganço, que marca o fim dos estudos e a entrada no mundo "real" dos adultos e da vida social "normal". A Praxe de curso, à imagem dos outros rituais, alterna os momentos solenes com outros mais ligeiros (Leach, 1982: 135). Possui a sua própria temporalidade sagrada, que adia o tempo profano dos estudos: a Universidade funciona em "marcha lenta", sem que um novo ciclo tenha ainda realmente "arrancado". Isto acontece, embora a comissão da Praxe de curso procure impor um calendário "cronológico" secularizado e racionalizado.

Pode acontecer que várias Praxes de curso ocorram no mesmo dia, enchendo a Alta de grupos de "doutores" e de caloiros de diferentes áreas ou Faculdades, que se deslocam cantando e gritando. Estes grupos formam-se sobre uma base unissexuada, ou congregando rapazes e raparigas "doutore/as" com os/as "seus/suas" caloiro/as igualmente misturados. Neste caso, a regra determina que a Praxe, no sentido de acção de praxar, seja efectuada entre pessoas do mesmo sexo, conforme o Código da Praxe de

\footnotetext{
${ }^{22}$ Este juramento é sem dúvida um vestígio e um "desvio" do acto obrigatório para todos os novos estudantes, até 1910 , de procederem a um juramento no momento de serem integrados na corporação dos "mestres e estudantes".

${ }^{23}$ Dados retirados do Código da Praxe de Évora, intitulado C.E.G.A.R.R.E.G.A. (1987), e de conversas mantidas no terreno.
} 
1993 (art. 250) ${ }^{24}$, embora distintas hierarquicamente, enquanto, por costume, são os caloiros do próprio curso a ser praxados. Uma observação atenta permite perceber a evolução da atitude dos caloiros e o processo de aprendizagem dos elementos sonoros do ritual (cânticos, grito de curso, hino). Estes dois aspectos são orientados pela ideia de que a passagem de uma relativa apreensão, por parte dos neófitos, a uma adesão mais ou menos unânime às regras do jogo é favorecida pela assimilação do conteúdo do ritual, portanto a sua compreensão (imanente), assim como pela assimilação da forma "normal" de interacção com os mais velhos, até ao ponto de lhes caber a iniciativa, sem contudo subverter as funções hierárquicas próprias de cada indivíduo ou, antes, dos grupos (como, aconteceu, por exemplo, com uma Praxe de curso da Psicologia).

O desenrolar das acções revela um percurso orientado, que nestes últimos anos se tornou num itinerário previamente planificado e enquadrado pelos mais velhos. A trupe parte da Faculdade a que pertence e dirige-se para lugares semi-públicos e centros simbólicos: Largo da Porta Férrea, Praça D. Dinis, Praça da República. Este périplo ritual, feito de gestos codificados e de expressões sonoras, age como marca cultural de um território, ancorado na Alta, e como espacialização de uma entidade académica (Frias, 2002a). Trata-se de um verdadeiro percurso, no sentido de Michel de Certeau: da tomada de posse prática de um espaço convertido em território. Esta apropriação colectiva de um perímetro que se circunscreve caminhando - com as suas polaridades, os seus eixos, os seus centros - varia no tempo, segundo as gerações e a morfologia urbana. Em parte imprevíveis e espontâneas, as deambulações acabam por desenhar, a prazo, uma cartografia topográfica e simbólica: uma "geografia da Praxe" (Lamy, 1990: 396).

Este quadro temporal restrito corresponde a uma Praxe de curso familiar, circunscrita ao espaço íntimo de uma Faculdade, até mesmo de um núcleo. Contrasta com a densidade histórica, se não mítica, de uma Praxe maiúscula - que circula, é um facto, a outros níveis, em outros espaços e, de bom grado, revelada a "estranhos". Esta Praxe é a das instituições universitárias e praxísticas: está presente nos discursos autorizados do Reitor, do Dux, do presidente da AAC ou de praxistas. ${ }^{25}$

\footnotetext{
${ }^{24}$ Observe-se uma evolução nos costumes, no que respeita a este ponto, entre o Código de 199 e o de 2001: este último texto, numa preocupação de "igualização" (relativa) dos sexos face à Praxe, suprimiu este artigo. O que não significa que o hábito não se mantenha. O último Código da Praxe, em uso de facto desde 2002, será posteriormente assinalado C.C., salvo indicação em contrário. ${ }^{25}$ Não é raro ouvir estas figuras oficiais, em situações formais (discursos intra-académicos, proferidos nos media ou dirigidos ao Governo), referirem-se a uma "especificidade da Universidade de Coimbra" (reitor), abrangendo, num todo único, a história da instituição, a Academia, o estudante de Coimbra, o espírito académico e as tradições "típicas". Assim, o antigo presidente da AAC,
} 


\section{V - Características das repúblicas}

As repúblicas estiveram durante muito tempo associadas à praxe, transmitindo os seus costumes através das gerações, muito embora após 1980 a maioria delas se tenha distanciado dos rituais praxistas ou de alguns dos seus aspectos.

Numa primeira aproximação, as repúblicas de Coimbra são casas comunitárias de estudantes, autónomas e auto-administradas, cujos membros estão ligados por laços económicos e afectivos. Se é possível estabelecer uma continuidade histórica entre as casas de estudantes e as actuais repúblicas, existe sempre o risco de cair no anacronismo e no a-historicismo. Com efeito, tudo muda neste domínio, à imagem do que sucede com a Universidade e com a globalidade da sociedade. O que se modifica são os tipos de estrutura, o grau de independência e de institucionalização, os hábitos internos, o estatuto dos residentes, as formas de relação, as características do estudante - a começar pelo nome de república, que, segundo se crê, aparece nos textos apenas no início do século XIX, sob a influência do período liberal, embora existam, em Coimbra, casas alugadas a estudantes desde o princípio do século XVI. ${ }^{26}$

Uma república tem a dimensão de uma casa, por vezes espaçosa. É habitada por um número de pessoas que vai de 6 a 10, aproximadamente. A este número, é preciso acrescentar 2 a 7 comensais que partilham as refeições. Apesar de existirem quartos duplos, os quartos individuais tornaram-se norma. Acontece que duas camas num mesmo quarto sejam ocupadas por um recém-chegado e por alguém mais antigo. Favorece-se assim a adaptação do que chegou por último ao espírito da casa e aos seus membros. De um modo geral, uma casa comporta, para lá dos quartos, um ou dois quartos de banho, uma sala comum para receber as visitas e passar os serões, uma biblioteca e uma cozinha onde, numa grande mesa, se fazem as refeições em comum. Todas as casas adoptaram uma forma autónoma de gestão, que funciona rotativamente. Esquematicamente, há "ministros” das finanças, dos assuntos externos, etc.; os "semanais" (chamados "kayds" na república

Hugo Capote, numa entrevista ao jornal Público (23/10/1999), fala da Praxe como sendo "o resultado de sete séculos de vivência académica". A identidade académica encontra-se naturalizada, uma vez que, "quando chega a Coimbra, o aluno herda uma espécie de código genético, que o faz perceber o sentido e a essência de todas as práticas". O Código da Praxe de 1993 (p. 7) põe em relevo, a este respeito, "uma vivência especial e diferente, gerada e desenvolvida em Coimbra ao longo de séculos e gerações"; uma "Academia de Coimbra [que] é a personificação de uma cultura única (...) que vincula as gerações..." ou uma "Praxe [que] é uma das tradições da Universidade de Coimbra, e como tal representa uma das belezas desta academia secular". Termos ou expressões como estes - "vivência", "ao longo de séculos", "gerações", "cultura única" - veiculam uma visão do mundo universitário unitária e continuísta.

${ }^{26}$ Sobre a história do alojamento de estudantes na Europa, ver Frias (2002b). 
dos Prá-Kys-Tão) encarregam-se de pôr a mesa ou de ajudar a cozinheira ${ }^{27}$, e um/a "administrador/a" (chamado "Shérif" na Bota-Abaixo) gere a alimentação durante um mês. Acontece que uma única tarefa, como o telefone ou o orçamento, seja assumida por cada um dos membros, segundo uma lógica rotativa: "a vez". Uma vez por semana, uma ou duas pessoas encomendam e fazem entregar nos Serviços Sociais da Universidade alimentos comprados com $50 \%$ de desconto. ${ }^{28}$ Todos os anos uma casa organiza um centenário - ou, de dez em dez anos, um milionário - para comemorar o dia da fundação da república. Nessa ocasião, regressam alguns dos antigos membros para partilhar uma refeição, um ou vários copos, e para reencontrar um ambiente festivo e amigável entre as gerações actuais e das outras repúblicas. É frequente que se organizem então actividades culturais com recurso à música (fado, cantos ao desafio), à poesia ou a exposições ${ }^{29}$.

As casas são alugadas a entidades particulares por um montante muito baixo: entre 25 e 50 euros mensais. Algumas constituíram-se em associação, desde a década de 1990. A maior parte é mista há menos de 25 anos. Em 2002 existem vinte sete repúblicas, duas das quais são femininas: Rosa Luxemburgo, fundada em 1972, e Marias do Loureiro, em 1993. Alguns testemunhos referem-se, aparentemente, a "repúblicas femininas" que teriam existido a partir dos anos de 1920. Este facto parece ser corroborado pelo texto de uma viajante francesa da mesma época (Jean-Javal, 1931). Atendendo a alguns dos traços referidos, como as tarefas rotativas e a autonomia, estas residências parecem-se, de facto, com uma república. É provável que essas casas funcionassem à imagem das repúblicas masculinas, mas talvez com um nível mais baixo de turbulência e bebida. O que faz transparecer a lógica do dual code, que distingue, consoante o sexo masculino ou feminino, os comportamentos sociais e os valores colectivos atribuídos a esses comportamentos. As casas femininas, locais de uma actividade católica, tiveram de se estruturar, de facto, por mimetismo, mas sem que as raparigas frequentassem as casas dos rapazes. Esta separação verifica-se, aliás, na vida académica em geral, uma vez que as raparigas não usam o fato tradicional, a capa e batina, e quase não participam nas Praxes nem na Queima das Fitas, antes de 1950, altura a partir da qual se verifica o aumento da frequên-

\footnotetext{
27 Algumas repúblicas não têm cozinheira (chamada "cumadre", à maneira de Ouro Preto, no Brasil), quer por opção (as Marias, incluindo os elementos efectivos e à experiência, revezam-se semanalmente na cozinha), quer para favorecer um maior envolvimento dos membros na casa e economizar [Prá-Kis-Tão, Ninho dos Matulões), quer porque problemas passageiros de ordem financeira impedem o pagamento do salário à cozinheira.

${ }^{28}$ Nos actuais Galifões, o caloiro da casa deve ir, durante um ano, buscar o pão às cantinas, em sinal de "obediência".

${ }^{29}$ Sobre a república como lugar - esquecido - de uma produção cultural e estética, ver Frias (2002c).
} 
cia feminina nos estudos superiores. $\mathrm{Na}$ realidade, apenas as repúblicas masculinas são reconhecidas e legítimas, incluindo nas memórias oral e escrita dos antigos. Uma expressão de Dionysia de Mendonça vai, de resto, ao encontro de uma tal hipótese: "A residência dos Palácios Confusos, a que às vezes chamávamos a nossa 'República', como aparece aqui e acolá no nosso 'Diário'...”. Portanto, a palavra "república" é aqui uma designação de conveniência e restringe-se apenas aos membros, não sendo difundida, além disso, senão num registo escrito, interno e privado.

A residência estudantil "tradicional" de Coimbra caracteriza-se por uma forma de vida colectiva e por uma comunidade de sentimentos. O espírito de solidariedade e de fraternidade não impediu, antigamente, a existência de uma hierarquia entre os membros, e hoje não impede as diferenças estatutárias. Antes de 1969, o título de presidente ou "Mor" (de majus: "maior") constitui a marca de uma hierarquia respeitada. Esta baseia-se na antiguidade que, por sua vez, legitima o exercício de uma autoridade tradicional, à maneira da hierarquia no seio da Praxe Académica ou da Universidade. O critério de antiguidade de residência permite ao Mor escolher o seu quarto ou, talvez, ser o mais ouvido nas "reuniões da casa"; na república dos Fantasmas e numa "reunião de casa", o seu voto conta mais do que o dos outros (mas este é um caso isolado). Ao atenuar-se, a sua autoridade tornou-se, contudo, mais de ordem moral. O Mor faz parte dos "elementos efectivos" que são definitivamente aceites por unanimidade, por ocasião de uma votação em "reunião de casa", onde funciona uma real democracia participativa. Depois de uma discussão com o candidato "à casa" e de uma votação por unanimidade entre os elementos efectivos, o novo elemento fica "à experiência" (ou "cabide" na república do Rapó-Táxo) de seis meses a um ano. Finalmente, o nome de uma república, a "república Spreit-ó-Furo" por exemplo, designa a entididade residencial e, ao mesmo tempo, a unidade formada pelos seus habitantes - o conjunto dos elementos à experiência e dos efectivos, com excepção dos comensais.

A estes indivíduos que residem e comem no que eles consideram ser a sua casa, é preciso acrescentar os "comensais", que apenas partilham as refeições colectivas. Amigos ou, então, viajantes de passagem encontram facilmente a porta aberta (no sentido próprio, até há pouco tempo), uma refeição e uma cama: são "convidados", do mesmo modo que os amigos de um dos elementos da casa vêm partilhar uma refeição. A chamada para as refeições faz-se simplesmente com a ajuda da voz ou então graças a um sino, a que se segue o anúncio gritado: “À palha (seus animais)!”. O último estudante integrado, portanto "à experiência", é geralmente um "caloiro de casa". A sua designação pode variar: o "menino do povo" nos Bota-Abaixo ou o "homem 
da palha" no Palácio da Loucura. Actualmente, a designação de "caloiro", do mesmo modo que outras manifestações da Praxe, pode ser recusada. É o que acontece, nomeadamente, nas repúblicas Marias do Loureiro, Inkas ou Prá-Kys-Tão. Se o último a ser integrado se torna num elemento igual dos outros (embora, na qualidade de neófito, ele "esteja lá para aprender e saber ouvir", segundo as palavras de um Mor), até ao ano de 1960 ocupou o nível inferior da hierarquia interna. Esta posição ingrata faz recair sobre ele as tarefas menos agradáveis e, por parte do grupo, as humilhações mais ou menos rituais, mas não destituídas de humor e brincadeira.

Em Coimbra, a palavra "república" tem um sentido genérico. Desde 1948, data da criação do Conselho de Repúblicas (CR) ${ }^{30}$, distinguem-se três tipos de "repúblicas", com uma conotação ligeiramente hierárquica. O que depende, também neste caso, da antiguidade da casa enquanto república. Por ordem crescente, trata-se do solar, da república (propriamente dita) e da real república. Foi assim que o solar Marias do Loureiro passou a república, em 16 de Julho de 2003, na sequência de um Conselho de Repúblicas reunido na Prá-Kys-Tão. Os últimos Estatutos do CR, refundidos em 1986, aboliram a distinção hierárquica entre estas três categorias de casas. Deste modo, se o solar tem o direito de participar e de votar num CR, não o pode "convocar", diferentemente do que sucede com os outros dois tipos de casa. No entanto, pode passar estrategicamente por uma casa amiga ou, a fortiori, pela república sua "madrinha" ${ }^{31}$, a fim de tratar de assuntos e de defender os interesses respeitantes ao conjunto das casas, ou de tomar colectivamente uma posição social ou política sobre uma determinada questão, como a das propinas nos anos de 1990. A atenuação da hierarquia entre estas entidades residenciais é visível, por exemplo, no facto de certas repúblicas terem conservado o nome de solar, como os Kapangas. Ao mesmo tempo, a expressão "ao serviço da Praxe", presente nos primeiros Estatutos do CR, em 1948 (art. 1), desapareceu com o movimento contestatário das tradições e das hierarquias (académicas e sociais) em 1969 e, sobretudo, em 1974. A partir desta data, é o conjunto da Praxe Académica que fica suspenso, incluindo, no que respeita às repúblicas, o CR. Nessa altura, a designação de "república" foi substituída por outras, como "comuna”. Esta radicalização verificou-se também na adopção de nomes de heróis

\footnotetext{
${ }^{30}$ Sobre o Conselbo de Repúblicas, cf. Frias (2002b).

${ }^{31}$ No momento do projecto de lei sobre a despenalização do aborto em Portugal, em 1998, as Marias puderam assim "convocar" um CR, graças ao apoio dos seus vizinhos e padrinhos, os Baco. Note-se que o apadrinhamento entre casas resulta do facto de que, para passar a solar e depois a república, a casa candidata é "apresentada" por uma república reconhecida, durante um CR. Uma tal medida reforça - ou tece - laços feitos de entreajudas, visitas recíprocas e, eventualmente, de relações amorosas que podem resultar em casamento.
} 
revolucionários, como o de Rosa Luxemburgo, escolhido num período fortemente politizado (1972). A oposição à Praxe levou, actualmente, a uma espécie de separação - se não oposição - entre a Praxe, nomeadamente o Conselho de Veteranos que a representa, e o CR.

Os três Códigos da Praxe de Coimbra (1957, 1993 e 2001) referem-se à república como "o conjunto de estudantes que vivem em comunidade doméstica”. Esta definição é demasiado ampla, uma vez que, em Coimbra, existem casas que não são repúblicas, mas onde se vive em "comunidade doméstica", como é o caso dos Cow Boys. Por outro lado, os Symbas, embora ostentem o nome de solar desde 1962, perderam o título de república e o lugar no CR, por razões de ordem política que datam dos anos de 1960. A definição dos Códigos é, além do mais, incompleta, porque, para que uma república exista tem de ser votada e reconhecida pelo CR, sem preencher necessariamente todas as condições formais, nomeadamente a "inauguração oficial", previstas pelo Código (1993: arts. 201 e 202).

As repúblicas desempenharam um papel activo durante os conflitos académicos de 1961 e 1969, no tempo do Estado Novo. Agiram como espaços de protecção a opositores (Mário Soares faz uma conferência na república dos Kágados, em 1969), através do jornal O Badalo ou da criação de uma lista única e unitária. Esta lista permitiu que os estudantes ganhassem as eleições para a Associação Académica (AAC), em 1961, contra a Comissão Administrativa imposta pelo Governo, desde meados dos anos de 1930. Alberto de Sousa Martins ou Celso Cruzeiro, entre outros leaders da contestação de 1969, eram "repúblicos". Entre 1969 e 1974, as repúblicas passaram de um praxismo "cultural" a um anti-praxismo que, na época, era de conotação política. Em 1982 e 1986, o Estado tomou medidas no sentido de proteger as repúblicas, reconhecendo-lhes um valor patrimonial e, em relação a algumas, financiando obras de restauro.

Cada casa tem o seu nome. Este pode partir de um jogo de palavras (Prá-Kys-Tão, Kágados, Bota-Abaixo, Fantasmas, Rás-Te-Parta, etc.), da origem geográfica dos membros (Corsários das Ilhas, Solar dos Estudantes Açoreanos, Kimbo dos Sobas, Farol das Ilhas), pode referir-se à loucura, à bebida ou ao jogo (Palácio da Loucura, Baco, Bota-Abaixo, Trunfé-Kopos), ao "meio" (Ninho dos Matulões), a valores de virilidade (Galifões), às mulheres (Ay-ó-Linda, Spreit-ó-Furo, Boa-Bay-Ela) ou à cozinha (Rapó-Táxo). A identidade nominal pode ainda ter origem num acontecimento histórico ou numa personagem política ( 5 de Outubro, Rosa Luxemburgo), numa referência exótica (Inkas) ou, simplesmente, no lugar ocupado: Marias do Loureiro, República da Praça, Solar do Kuarenta ou Solar do 44. Note-se que esta última foi promovida a república durante um CR em 2002. 
Todas as repúblicas possuem uma bandeira negra onde são visíveis o nome e um logotipo inspirado numa visão humorística, na Praxe (as Marias ou as Rosas), na bebida, nas mulheres, etc. Por vezes, é acrescentada a expressão praxística "Dura Praxis, sed Praxis". Mas algumas casas, como as Marias ou os Kágados, já pensaram em retirá-la. Todas possuem um grito: "E-K-A", para os Kágados, “A-R-R-E”, para a Boa-Bay-Ela ou "Hó égua!", para os Prá-Kys-Tão. ${ }^{32}$ As repúblicas distinguem-se igualmente pelo hino respectivo. Sirva como exemplo o da Boa-Bay-Ela: "Estas meninas de agora / Boas lascas a valer/Suspiram de hora a hora / Passam a vida a dizer / Que a malta mais agradável/Desta Coimbra tão bela/É a malta formidável/E piramidável / Da Boa-Bay-Ela”. Neste exemplo representativo, co-existem a afirmação identitária, a valorização da casa e a afirmação de um ethos masculino remetendo para um período em que os estudantes eram a maioria na Universidade e os únicos a residir nas repúblicas. Acrescente-se uma referência a Coimbra e a uma particularidade da república (cf. "Piramidável").

Por fim, é possível dar uma definição mais completa de república, pelo menos na versão conimbricense e actual. Pode ser caracterizada a partir de vários critérios convergentes, marcados pelo signo do vínculo. Assim, uma república de estudantes é uma casa comunitária que assenta na co-habitação dos seus membros "efectivos" e "à experiência", masculinos e/ou femininos, e na qual se integram os "comensais". Esta co-presença de pessoas agregadas (colegas de curso, conterrâneos, indivíduos recomendados) prolonga-se numa linha geracional: os "antigos". A república favorece um elevado número de interacções individuais ou de grupo, e uma forma de cooperação participativa e rotativa. Esta cooperação económica faz-se acompanhar de um estilo de vida e de uma confraternidade que se identifica com um companheirismo convivial. Aos laços de reciprocidade e a uma ética de confiança, que unem os membros entre si, acrescenta-se o sentimento de pertencer a uma mesma casa. Esta é constitutiva de uma unicidade intra e inter-geracional. As repúblicas ligam-se entre si através do Conselho de Repúblicas e, normalmente, por relações mútuas de natureza amigável, intelectual ou cultural.

\section{VI - Patrimonialização}

Os costumes não aparecem como "tradições", à maneira de um objecto face a um sujeito, perante os olhos dos actores que os vivem e, de alguma forma, os encarnam. Pertencendo, antes de mais, ao âmbito das experiências colectivas, estes costumes têm a plasticidade e a informalidade do vivido, e

\footnotetext{
${ }^{32} \mathrm{O}$ estilo e o ritmo destes gritos derivam sem dúvida do grito académico nacional - "F-R-A" que serve de modelo a outros. Veja-se, por exemplo, in extenso, o grito dos Kágados: K...A...KA $/ K \ldots . . . K E / K \ldots I \ldots K I / K \ldots O \ldots K O / K \ldots U \ldots K U / K a ́ \ldots g a \ldots$ dos (3 vezes) / Aguenta o gado.
} 
obedecem às regras implícitas da prática. Ora, o mesmo não se verifica com uma Praxe Académica "tradicional" e, a fortiori, tradicionalista.

Em Coimbra, há discursos individuais e institucionais que concebidamente se referem a uma Praxe Académica que se confunde com a história da Universidade. Um determinado uso social - e abuso científico - "da tradição" pode levar, passando do substantivo à substância, como diz Wittgenstein, a considerá-la única e eterna. Mas a análise socio-histórica faz aparecer variações e distinções. Dos fins do século XIX até à actualidade, tudo mudou em matéria de Praxe Académica, paralelamente ao que sucedeu com a instituição universitária e as suas cerimónias.

As transformações manifestam-se em vários registos e segundo intensidades variáveis. Podemos indicar, esquematicamente, as etapas importantes e observar as principais modificações. Estas mudanças verificam-se no abandono efectivo de certos elementos: por desuso (levar os caloiros no burro; roubos de patos ${ }^{33}$; desaparecimento de palavras, como "candeeiro" ou "formigão" ${ }^{34}$, e de referências à tricana); por moda (gorro) ${ }^{35}$; devido à lei (capa e batina e cerimónias universitárias, em 1910), às críticas contra os "excessos" estudantis (canelão na Porta Férrea, patente, hierarquias) ou devido a transformações morfológicas (sociabilidades na Rua Larga, antes das demolições de 1940, Queimódromo, desde 2000). Também ocorrem novidades - por empréstimo paródico (Latadas, por volta de 1880; Centenário da Sebenta em 1899, retomado sob a forma do Enterro do Grau em 1905 e, depois, da Queima das Fitas); por criação (fado, tunas, hino, livro de finalistas), por inovação dos organizadores (reunião de todas as Faculdades na Queima de 1926, introdução do baile de gala em 1933 e de um Sarau), por imitação e iniciativa de um curso (cartola e bengala, venda da pasta) ${ }^{36}$. Por

\footnotetext{
${ }_{33}$ Um velho fresco mural situado na república dos Prá-Kis-Tão dá testemunho de tal costume. Estes roubos "rituais" foram hoje substituídos pelo furto de sinais de trânsito.

34 "Candeeiro" designava, antigamente, o quartanista, em referência à vela de que ele se servia para estudar (como gíria escolar, o termo aparece já em 1792, no Palito Métrico); "formigão" era aplicado ao estudante de teologia.

35 O gorro veio de Lisboa por volta de 1730 , ficou mais curto (como a batina) e mais raro entre as "tradições" por volta de 1880, de acordo com Coelho (1902: 127), e ressurgiu em 1943 (Soares, 1985a: Novembro), por ocasião, segundo parece, da reconstituição de cenas históricas para um filme. Hoje, são sobretudo alguns raros "veteranos" que o usam.

36 Para desenvolver apenas este aspecto, Soares (1985b: 356-357) refere que, no dia da sua "reunião de curso" (uma semana depois da sua formatura!), "o curso do V ano médico que usou fitas largas no ano lectivo de 1931-32, teve grande importância na 'criação' de costumes académicos - a 'venda da pasta' (...) e também na 'reafirmação' de outros costumes antigos”. É o caso, nomeadamente, da invenção do uso das cartolas na festa da Queima de 1932. A bengala e a cartola são introduzidas por ocasião de uma fotografia de curso tirada nas escadas da capela da Universidade, em que os condiscípulos usam "trajes respeitáveis, com chapéu alto, coco, chapéus de revirão, bengalas e outros acessórios de vestuário, a lembrar individualidades prestigiadas e respeitáveis que se tivessem formado ainda no século XIX”.
} 
outro lado, verificam-se alterações no calendário de um evento (em 1949, a Latada passa de Maio para Novembro, a Queima das Fitas é antecipada de 26 para o princípio do mês de Maio), nos itinerários (a Queima das Fitas estende-se da Alta à Baixa), no financiamento das festas (sponsoring), na publicitação das actividades (marketing, media, a Queima das Fitas torna-se numa festa da Academia e da cidade), na forma dos acontecimentos (a passagem de uma algazarra espontânea para uma Latada carnavalizada, preparada e uniformizada), na reificação dos costumes (codificação e folclorização da Praxe), na utilização política dos costumes (luto académico, canto de intervenção, comemoração da Tomada da Bastilha) ou até mesmo na sua rejeição depois de 1969-1974. São ainda observáveis algumas variações - por restrição (os alunos do liceu já não usam capa e batina desde o fim da década de 60, tal como já não são praxados na qualidade de "bichos") ou por extensão às raparigas, quer da Praxe em geral, mas "adaptada" e monossexuada (trupes, rasganço, etc.), quer da capa e batina emblemática, a partir do Código de 1957. A estas alterações, é necessário acrescentar a passagem de uma esfera para outra, com a deslocação - ou extensão - do registo das práticas ou das experiências concretas para o das imagens discursivas ou escritas, perenizando em traços "típicos" elementos desaparecidos, como a tricana, ou fixando idealmente formas passadas de sociabilidade, como a boémia. Finalmente, em pouco mais de um século, assiste-se a uma reconfiguração do sentido dos objectos - ou da sua representação (a capa e batina "igualitarista" torna-se distintiva e hierárquica) -, das imagens do estudante (do cábula e do "urso" ao elegível) e do contexto universitário e social (da boémia literária ao desemprego dos licenciados...).

Estes pontos de referência cronológicos e esta história positivista permitem apenas estabelecer a série dos elementos factuais - e a sua variação em matéria de tradições académicas. Mas não são explicativos em si mesmos. Há dois conceitos que nos podem permitir esclarecer a trama histórica da Praxe Académica e das suas mecanismos sociais.

Em primeiro lugar, o da patrimonialização. Esta noção articula uma dupla dinâmica global. A primeira tem por base um processo de legitimação que confere um valor artístico, histórico, cultural, ideal ou simbólico a uma construção, a um objecto, a uma prática ou a um espaço. A segunda assenta na valorização social de uma determinada entidade, reconhecendo-lhe um interesse local, nacional ou global. Há que acrescentar a este procedimento formal uma lógica de natureza museológica, que consiste numa política de conservação e numa encenação de objectos "culturais" ou "artísticos", destinados a serem representados e contemplados. É depois de uma operação social deste tipo, em que se mistura uma poderosa carga de sagrado e de convicção, que um "património" fica definido e visível. Esta dinâmica deter- 
mina igualmente uma certa forma de o desfrutar - com regras e com um olhar estetizante. E, ao mesmo tempo, implica um tipo de administração racional dos "bens" culturais ou materiais (Frias, 2001).

A ideia de patrimonialização remete para uma outra: a de "objectificação", proposta por Richard Handler (1988). Este segundo conceito define o processo de transformação de uma cultura num "objecto" representado, de ordem material ou não. E isto, graças a uma descontextualização, a uma transferência de sentido e mesmo a uma alteração de lógica, em particular com a constituição de um folclore, de um museu académico ou de um património (Frias, 2002d). Finalmente, as noções de patrimonialização e de objectificação ajudam a delimitar o sentido e o alcance do processo de estetização, processo este que, aliás, engloba os anteriores (Frias e Peixoto, 2002). Estes conceitos permitem compreender a evolução da Praxe Académica que, em pouco mais de um século, passa de costumes vividos e "praticados" a tradições - admiradas, lamentadas ou criticadas - e, mais recentemente, a tradicionalismo.

Os comportamentos rituais e as cerimónias encontram na Alta histórica e na Universidade uma parte da sua significação e as condições da sua performance. As tradições académicas favorecem um jogo de espelhos, onde o colectivo se reflecte idealmente e se dá a ver através da imagem controlada de uma comunidade pacificada. Alta e Praxe constituem também o substrato e a substância donde flui a carga simbólica de que a Universidade se alimenta, tanto mais quanto maior é a tendência para se "racionalizar". Um tal processo foi, sem dúvida, desencadeado desde o aparecimento da Praxe. Recentemente acelerou-se, sob o peso crescente das tecnologias e com a emergência de uma relação instrumental entre os estudantes, transformados em utentes, e a Alma Mater, reduzida a uma instituição distribuidora de diplomas em massa. Este "desencantamento" fez-se, pois, acompanhar de uma "desritualização" e de uma "dessacralização" da Universidade. No entanto, desde os anos de 1980 que se assiste, se não a uma "ressimbolização", pelo menos em Coimbra a uma "restauração", e, nas outras cidades universitárias, a uma "invenção" dos costumes académicos. O reforço das tradições no âmbito escolar acentua o processo de patrimonialização das cidades, que optam pela via do tradicionalismo ao tornarem-se cada vez mais codificadas, institucionalizadas e até "folclorizadas".

\section{Conclusão}

Se a análise a que se procedeu parece ter um efeito de desencanto relativamente ao "espírito académico", a explicação racional, relativista e causal, por si só, não pode apagar o intenso halo de imagens e afectos que rodeia a Praxe Académica. Isto, porque o vivido possui o seu sentido próprio e a 
sua força de inércia. Este vivido resiste menos a um suposto "mistério" irredutível da vida social perante as pretensões objectivistas da ciência, do que à tentativa, por parte do sociólogo, de encontrar a explicação dos comportamentos colectivos e dos seus mecanismos.

Uma ilusão difundida situa o início da Praxe Académica numa época recuada. A mesma lógica, misturando convicções e representações colectivas, considera a actual Universidade uma instituição "fundada por D. Dinis". Estes mitos, alimentados, possuem decerto uma razão e têm a sua eficácia. Baseiam-se na aparência de um continuum material (Alta; Paço das Escolas), textual (biografias e Códigos; Estatutos e cronologias) e espiritual (espírito académico; Alma Mater). Estes três registos funcionam como suportes estratégicos de uma memória social selectiva.

A reactivação de histórias localizadas num espaço social e imaginário (Alta, rua Larga, repúblicas, Porta Férrea, Penedo da Saudade, etc.); a publicação institucional da parte "histórica" dos arquivos da Universidade, obras "fundadoras" de estudantes e Códigos regulamentadores das tradições; finalmente, a referência a um halo de sacralidade que envolve os "doutores", os mestres, a Universidade ou Coimbra - tudo isto forja uma identidade académica e universitária. Ancorado na linha do tempo, sobre a qual o presente e o passado parecem interpenetrar-se, este projecto identitário acaba por confundir-se com uma certa cultura letrada, pelo menos com a imagem de uma cultura como tal exibida perante a Academia de Coimbra e as outras. Se não unitária, pelo menos unificada em alguns discursos, esta cultura identitária é a da Praxe Académica, a das cerimónias do corpo professoral e a do património universitário.

Se no presente artigo, o nosso assunto é a Praxe Académica, perspectivada no quadro englobante e explicativo da Universidade no seu registo institucional e, sobretudo, sociocultural, a orientação da análise privilegiou um eixo cujos pólos são indissociáveis: lógicas das tradições e dinâmicas identitárias. Os poucos textos que existem sobre as tradições académicas portuguesas oscilam entre duas posições extremas e incompatíveis. A primeira consiste numa atitude em que a admiração e a ingenuidade rivalizam, levando a uma percepção encantada das práticas; este olhar estetizante é comum aos adeptos da Praxe e aos notáveis locais, dirigentes de associações folclóricas que recorrem a uma "história" edificante e, afinal, a-histórica. A segunda situa-se entre a crítica da Praxe Académica e a indiferença. Nenhuma destas duas posições tem em conta a complexidade do mundo universitário e a empiricidade dos factos. Ambas desatendem ao sentido das práticas e das representações, conduzindo ao juízo de valor - próprio, é certo, da implicação dos actores e da convicção que a fundamenta. No entanto, o investi- 
gador deve incluir no seu objecto estes aspectos como diferentes posições que as tradições suscitam, diversos graus de modalidades praxíticas, como dimensões constitutivas da Praxe e como vínculos internos à Academia.

Tentámos pôr em relevo uma parte das características sociais e culturais da Universidade e da Praxe Académica de Coimbra, observadas sob o ângulo das tradições e das identidades. O que daqui sobressai é a ideia de um mundo com múltiplas facetas, detentor da sua própria coerência e atravessado de tensões. Finalmente, só podemos insistir na necessidade de levar a sério a Praxe e a vida académica no seu conjunto, do mesmo modo que qualquer outro objecto legítimo em sociologia, em história ou em antropologia. "Levar a sério" quer dizer, nomeadamente, não ceder à tentação de as reduzir à gratuitidade e ao arbitrário, "ou seja, alguma coisa que nos poderia espantar ou escandalizar”, segundo as palavras em tom de censura que já Wittgenstein dirigia ao etnocentrismo e ao logocentrismo de Frazer.

Tradução de

Maria do Rosário Cunha

\section{Referências Bibliográficas}

AA.VV. (1997), História da Universidade em Portugal, I Volume, tomos I (1290-1536) e II (1537-1771), Universidade de Coimbra / Fundação Calouste Gulbenkian.

Andrade, Mário de (1957), Código da Praxe Académica de Coimbra. Coimbra: Coimbra Editora.

Araújo, Ana Cristina (org.) (2000), O Marquês de Pombal e a Universidade. Coimbra: Imprensa da Universidade.

Bourdieu, Pierre (1984), Homo academicus. Paris: Minuit.

Bourdieu, Pierre (1992), Réponses. Paris: Minuit.

Bouveresse, Jacques (1977), "L'animal cérémoniel: Wittgenstein et l'anthropologie", Actes de la Recherche en Sciences Sociales, $n^{\circ} 16,36-54$.

Braga, Teófilo (1892), História da Universidade de Coimbra, tomes I. Lisboa: Por Ordem da tipografia da Academia Real das Ciências.

Caron, Jean-Claude (1999), A l'école de la violence. Châtiments et sévices dans l'institution scolaire au XIXe siècle. Paris: Aubier.

C.E.G.A.R.R.E.G.A. (1987), Código Estudantil de Graus Académicos, Regulamentos e Regras de Exégese e Gírias Académicas da Universidade de Évora.

Clark, William (2002), Academic Manners, Ministries and Markets. University Press of Chicago.

Código da Praxe Académica de Coimbra [edição revista e actualizada por Pedro Cabral (Dux-Veteranorum)] (1993), Coimbra Editora. 
Código da Praxe Académica de Coimbra [Revisão e Actualização de João Luís Jesus Dux Veteranorum e alii] (2001), Coimbra: Magnum Concilium Veteranorum Editor.

Coelho, José Francisco Trindade (1902), In Illo Tempore. Estudantes, lentes e futricas. Lisboa: Portugália Editora.

Coimbra, Margarida Rosa Custódio Mota (1991), "Subsídios para o estudo da delinquência estudantil em Coimbra, 1871-1886”, Universidade(s), História, Memória, Perspectivas, vols. III, Congresso História da Universidade, $7^{\circ}$ Centenário, Coimbra: 321-330.

Costa, Alberto (ex-Pad'Zé) (1925), O Livro do Doutor Assis, Lisboa, 7. edição, (1905).

Coulon, Alain (1997), Le métier d'étudiant. L'entrée dans la vie universitaire. Paris: PUF.

Coutin, André (1969), Huit siècles de violence au Quartier latin. Paris: Stock, 1969.

Cruzeiro, Maria Eduarda (1979), "Costumes estudantis de Coimbra no século XIX: tradição e conservação institucional”, Análise Social, vol. XV(60), 795-838.

Cruzeiro, Maria Eduarda (1990), Action symbolique et formation scolaire. L'Université de Coimbra et sa Faculté de Droit dans la seconde moitié du XIXe siècle, thèse de sociologie, EHESS.

Celso, Cruzeiro (1989), Coimbra 1969. Porto: Afrontamento.

Delgado, Maria Rosalina Pinto da Ponte (1991), "Esturdias académicas do 'Anno Noticioso e Historico' (1740-1745), Universidade(s). História, Memória, Perspectivas, vol. 3, Congresso História da Universidade, $7 .^{\circ}$ Centenário, Coimbra, 233-241.

Estanque, Elísio, Nunes, João Arriscado (2002), “A Universidade Perante a Transformação Social e as Orientações dos Estudantes: O Caso da Universidade de Coimbra”, Oficina do CES, 169.

Fonseca, Fernando Taveira da (1995), A Universidade de Coimbra (1700-1771). Estudo social e económico. Coimbra: Imprensa da Universidade.

Frias, Anibal (1992), Les traditions étudiantes au Portugal. Rites.Fêtes.Jeux. Mestrado de Antropologia, Université de Nanterre.

Frias, Anibal (1998a), "Les traditions étudiantes au Portugal: entre continuité et innovation", A Alfa A, "Hacia una mutación de lo social", Europa-America Latina, 2, Ano 2, 131-152.

Frias, Anibal (1998b), "La Praxe dos caloiros: un rite de passage”, Recherches en Anthropologie au Portugal, 5, 11-39.

Frias, Anibal (2001), "Patrimoine et traditions étudiantes à Coimbra (Portugal): entre art et culture”, in Jean-Olivier Majastre e Alain Pessin (orgs.), Vers une sociologie des cuvres, tome I. Paris: L'Harmattan, 425-446.

Frias, Anibal (2002a), "Espace rituel et territorialité sonore à l'Université de Coimbra (Portugal)”, in Abel Kouvouama e Marie-Caroline Vanbremeersch (orgs.), Lisières et espaces sensibles. Paris: L'Harmattan. 
Frias, Anibal (2002b), “A Universidade e as Repúblicas de Coimbra (Portugal)”, in Otávio Luiz Machado (org.), Repúblicas de Ouro Preto e Mariana. Brasil: Laboratório de Pesquisa Histórica, UFOP.

Frias, Anibal (2002c), "Les Repúblicas d'étudiants à Coimbra”, Latitudes, 14, 41-49. Frias, Anibal (2002d), “'Patrimonialização' da Alta e da Praxe académica em Coimbra”, Actas do colóquio da APS (em CDRom).

Frias, Anibal (2003a), Le monde universitaire et la Praxe académica au Portugal. Cultures académiques et traditions étudiantes: l'Université de Coimbra. Thèse d'ethnologie. Université de Paris X-Nanterre.

Frias, Anibal (2003b), Politique et esthétique. Le canto de intervenção et les traditions étudiantes de Coimbra dans la décade 1960", Lusotopie (artigo proposto para publicação).

Frias, Anibal; Peixoto, Paulo (2002), "Representação imaginária da cidade. Processos de racionalização e de estetização do património urbano de Coimbra”, Oficina do CES, 183.

Geertz, Clifford (1999), Savoir local, savoir global. Les lieux du savoir. Paris: PUF (1986).

Handler, Richard (1988), Nationalism and the Politics of Culture in Quebec. Madison: The University of Winconsin Press.

Jean-Javal, Lily (1931), Sous le charme du Portugal. Paris: Plon.

Lamy, Alberto Sousa (1990), A Academia de Coimbra 1537-1990. História-Praxe-Boémia e Estudo-Partidas e Piadas-Organismos académicos. Lisboa: Rei dos Livros.

Leach, Edmund (1982), Rethinking Anthropology. Londres: The Athlone.

Mendonça, Dionysia Camões de (1984), "Residências Independentes para Universitárias: 1920-1974”, Boletim da AAEC, 14, 55-63.

Mauss, Marcel (1983), Sociologie et Anthropologie. Paris: PUF (1950).

Nobre, Carminé (1945), Coimbra de Capa e batina, vol. II. Coimbra: s.e.

Oliveira, Ernesto Veiga de (1984), Festas Cíclicas em Portugal. Lisboa: Dom Quixote.

Palito Métrico e correlativa Macarrónea Latino-portuguesa. Coimbra: Oficina da Coimbra-Editora, 1942 (1792).

Prata, Manuel Alberto Carvalho (2002), Academia de Coimbra (1880-1926). Contributo para a sua história. Coimbra: Imprensa da Universidade.

Raposo, Eduardo (1998), O papel sociocultural e político do canto de intervenção na oposição ao Estado Novo (1960-1974). Lisboa: Universidade Nova de Lisboa.

Revez, António Manuel Marques (1999), “Dura Praxis, Sed Praxis”. Relações de Poder e Moral na Praxe Académica da Universidade de Évora. Évora: Universidade de Évora, tese de Mestrado de Sociologia, 1999.

Roque, João Lourenço (1991), "Coimbra na 2." metade do século XIX. Estudantes e sociabilidade urbana. (Alguns aspectos)", Universidade(s). História, Memória, Perspectivas, vol. 3, Congresso História da Universidade, $7{ }^{\circ}$ Centenário, Coimbra, 257-275. 
Rüegg, Walter (1996), “Temas”, in Walter Rüegg (org.), Uma bistória da Universidade na Europa. Vol. I (coord. da edição : H. de Ridder-Symoens), As Universidades na Idade Média. Conselho de Reitores das Universidades Portuguesas. Lisboa: Fundação Eng. António de Almeida/Imprensa Nacional-Casa da Moeda, 3-31.

Sanches, António Nunes Ribeiro (1959), Obras. vols. I. Coimbra, Por ordem da Universidade de Coimbra.

Sapir, Edward (1967), Antbropologie. Paris: Seuil.

Soares, António José (1985a), Saudades de Coimbra. Vol. III. Coimbra: Livraria Almedina.

Soares, António José (1985b), Saudades de Coimbra. Vol. II. Coimbra: Livraria Almedina.

Torgal, Luís Reis (1993a), “Quid Petis? Os 'Doutoramentos' na Universidade de Coimbra”, Revista de História das Ideias, "Rituais e Cerimónias”, 15, 177-316.

Torgal, Luís Reis (1993b), "Instrução Pública' - O sentido e a força de um conceito liberal”, in José Mattoso (org.), História de Portugal, vol. 5 : “ O Liberalismo”. S. 1.: Editorial Estampa, 609-652.

Torgal, Luís Reis (1999), A Universidade e o Estado Novo. O caso de Coimbra: 1926-1961. Coimbra: Minerva História.

Van Gennep, Arnold (1981), Les rites de passage. Paris: Editions Picard (1909).

Vara, Flávio (1958), O espantalho da "Praxe" coimbrã. Lisboa: Salesiana.

Verger, Jacques (1997), Les gens de savoir en Europe à la fin du Moyen Age. Paris, PUF, 1997.

Waquet, Françoise (1998), Le latin ou l'empire d'un signe. XVIe-XXe siècle. Paris: Albin Michel. 